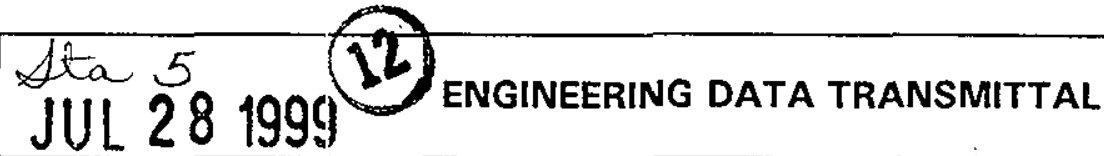

\begin{tabular}{|l|l|}
\hline $\begin{array}{l}\text { 2. To: (Receiving Organization) } \\
\text { Engineering Files }\end{array}$ & $\begin{array}{l}\text { 3. From: (Originating Organization) } \\
\text { WARP ENGINEERING }\end{array}$ \\
\hline $\begin{array}{l}\text { 5. Proj./Prog./Dept/Div.: } \\
\text { W-026/WRAP/WMH }\end{array}$ & $\begin{array}{l}\text { 6. Design Authority/Design Agent/Cog. Engr.: } \\
\text { E. V. dosRamos }\end{array}$ \\
\hline
\end{tabular}

8. Originator Remarks:

This EDT is to release the WRAP TRUPACT Operational Test Report.

11. Receiver Remarks: 11A. Design Baseline Document? $O$ Yes $\bigcirc$ No

\section{A. Design Baseline Document? $O$ Yes $\bigcirc$ No}

See USQ 99-111
4. Related EDT No.:

N/A

7. Purchase Order No:

$\mathrm{N} / \mathrm{A}$

9. Equip./Component No.:

$\mathrm{N} / \mathrm{A}$

10. System/Bldg./Facility:

$2336 \mathrm{~W}$

12. Major Assm. Dwg. No.:

$\mathrm{N} / \mathrm{A}$

13. Permit/Permit Application No.:

$\mathrm{N} / \mathrm{A}$

14. Required Response Date:

$\mathrm{N} / \mathrm{A}$

\begin{tabular}{|c|c|c|c|}
\hline (F) & $(\mathrm{G})$ & $(\mathrm{H})$ & $(\mathrm{I})$ \\
\hline $\begin{array}{c}\text { Approval } \\
\text { Desig- } \\
\text { nator }\end{array}$ & $\begin{array}{c}\text { Reason } \\
\text { for Trans- } \\
\text { mittal }\end{array}$ & $\begin{array}{c}\text { Origi- } \\
\text { nator } \\
\text { Dispo- } \\
\text { stion }\end{array}$ & $\begin{array}{c}\text { Receiv- } \\
\text { er } \\
\text { Dispo- } \\
\text { sition }\end{array}$ \\
\hline $\mathrm{SQ}$ & 2 & 1 & \\
\hline & & & \\
\hline & & & \\
\hline & & & \\
\hline
\end{tabular}

KEY
16

\begin{tabular}{|c|}
\hline Approval Designator $(F)$ \\
\hline $\begin{array}{c}\text { E, S, } Q, D O R \text { N } \\
\text { (See WHC.CM } W-3-5, \\
\text { Sec. 12.7) }\end{array}$ \\
\hline
\end{tabular}

17.
15

\begin{tabular}{|c|c|}
\hline $\begin{array}{c}\text { (A) } \\
\text { ttem } \\
\text { No. }\end{array}$ & (B) Document/Drawing No. \\
\hline 1 & HNE-3919 \\
\hline & \\
\hline & \\
\hline & \\
\hline & \\
\hline & \\
\hline & \\
\hline
\end{tabular}

DATA TRANSMITTED

(C) Sheet (D) Rev. No.

1. Approval
2. Release
3. Information

Reason for Transmittal (G)

4. Review

5. Post-Review

6. Dist. (Receipt Acknow. Required)

SIGNATURE/DISTRIBUTION

(See Approval Designator for required signatures)

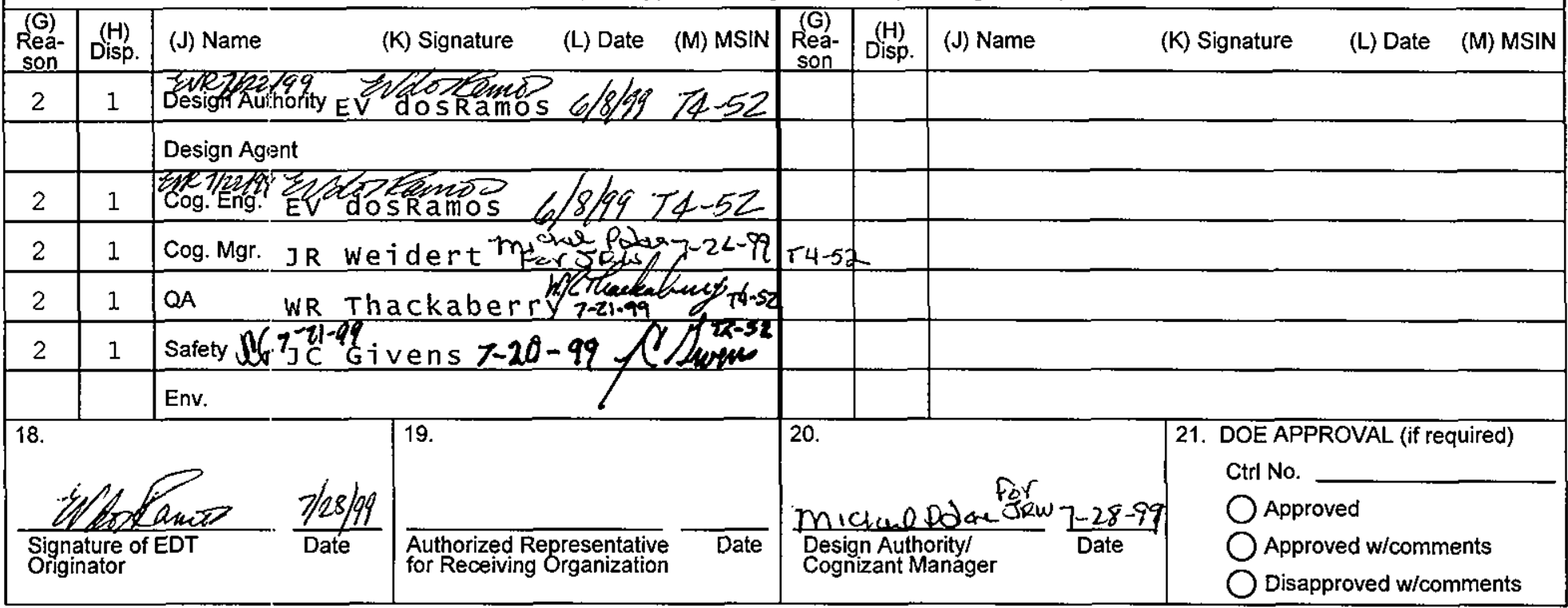




\title{
WRAP TRUPACT LOADING SYSTEMS OPERATIONAL TEST REPORT
}

\author{
EV Dos Ramos \\ Waste Management Federal Services of Hanford, Richland, WA 99352 \\ U.S. Department of Energy Contract DE-AC06-96RL13200

$\begin{array}{llll}\text { EDT/ECN: } & \text { EDT-623526 } & \text { UC: } 506 \\ \text { Org Code: } & 32600 & \text { Charge Code: } & \text { AJ60 } \\ \text { B\&R Code: } & \text { EW02J126 } & \text { Total Pages: } & 71\end{array}$ \\ Rey Words: OTR, Transuranic, WIPP, TS \\ Abstract: This procedure was performed to verify the TRUPACT System \\ operates in accordance with system design and specification.
} ** Apollo is a registered trademark of Conbraco Industries, Inc.,
Matthews, NC

TRADEMARK DISCLAIMER. Reference herein to any specific comercial product, process, or service by trade name, trademark, manufacturer, or otherwise, does not necessarily constitute or imply its endorsenent, recommendation, or favoring by the United States Government or any agency thereof or its contractors or subcontractors.

Printed in the United States of America. To obtain copies of this document, contact: Document Control Services, P.0. Box 950, Mailstop H6-08, Richland WA 99352, Phone (509) 372-2420; Fax (509) 376-4989.
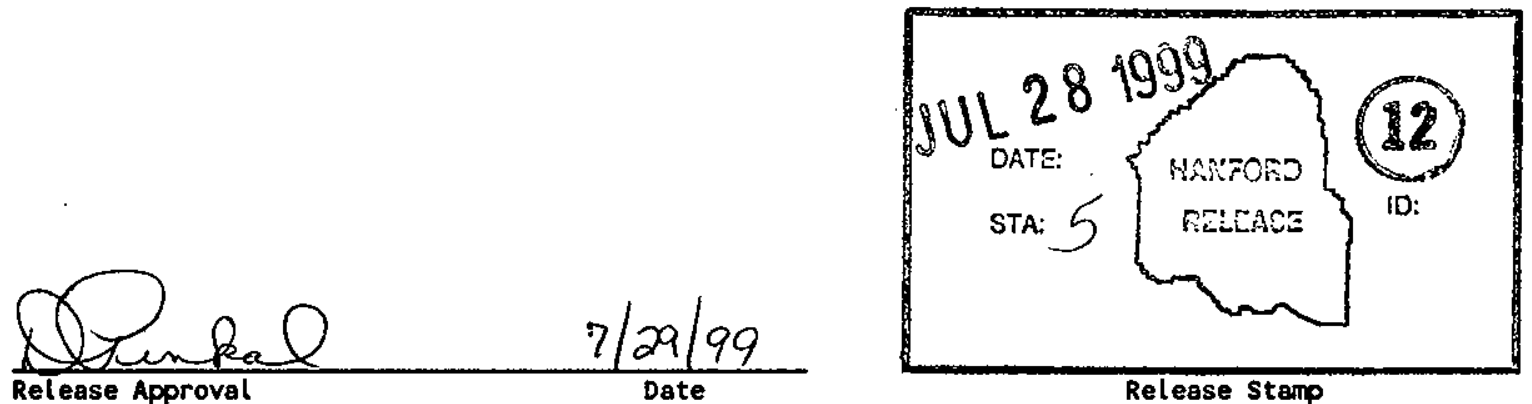


\section{SUMMARY}

This Operational Test Report documents the operational testing of the TRUPACT process equipment HNF-3918, Revision 0, TRUPACT Operational Test Procedure.

The test accomplished the following:

- $\quad$ Procedure validation

- Facility equipment interface

- Facility personnel support

- Subcontractor personnel support interface

Field changes are documented as test exceptions with resolutions. All resolutions are completed or a formal method is identified to track the resolution through to completion. 
Operational Testing - TRUPACT Loadout System

Operational testing of the TRUPACT process equipment is complete.

Test Engineer:

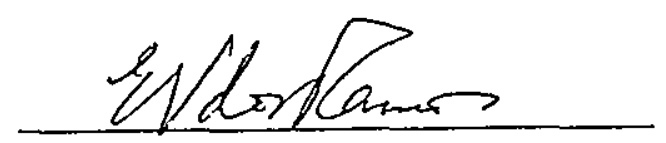

Test Director:

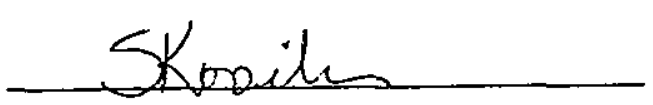

Date:

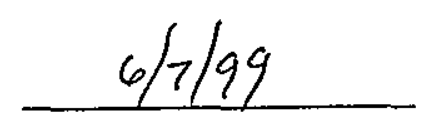

Date:

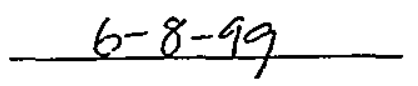


Waste Receiving and Processing Facility

\section{Operational Test Procedure \\ TRUPACT LOADING SYSTEMS}

E. V. dosRamos 


\subsection{PURPOSE}

1.1 This procedure has been prepared to verify the TRUPACT System (TS) operates in accordance with system design and specifications.

\subsection{INFORMATION}

2.1 Scope

2.1.1. This procedure will demonstrate the loadout operations for the following "components" and "systems" in the TS:

- Stretch Wrapper (ATR-003 released 11/04/96)

- TRUPACT Guide Tube Storage

- TRUPACT Reinforcement/Slipsheet Storage Rack

- TRUPACT Accumulation (Gravity) Conveyor

- TRUPACT Bridge Crane (ATR-004 released 11/04/96)

- Adjustable Center of Gravity Lifting Fixture - Government Furnished Equipment (GFE)

- Lift Fixture Leg Stands (GFE)

- TRUPACT II (Shipping Container) - (GFE)

- 'Outer Containment Vessel (OCV) Lid Stand

- Inner Containment Vessel (ICV) Lid Stand

- TRUPACT Loading Platforms (ATR-015 released 11/19/96)

2.1.2 Other interfacing systems outside this loadout operational testing workscope include the drum Discharge Conveyor, Drum Scale, Drum Pallet Laydown Area and Automated Storage and Retriever System, Compressed Air System, and Drum Discharge Jib Crane.

2.1.3 When possible, this test will demonstrate both mechanical and electrical operations for "local" and "remote" capabilities/functions.

2.2 Terms and Definitions

- HS - Hand Switch

- LOI - Local Operator Interface

- MCS - Monitoring Control System

- OCS - Operating Control Station

- OT - Operational Test

- PLC - Programmable Logic Control

- PI - Pressure Indicator

- PT - Pressure Transmitter

- RCT - Radiological Control Technician 


\subsection{Responsibilities}

2.3.1 Test Director (TD) responsibilities:

- Facility management appoints the Test Director and should be a qualified Operations Supervisor or Design Authority.

- Provides the necessary support equipment requested in OT Sections 4.0 and 5.0

- Records OT equipment status and data

- Conducts pre-job planning meetings - as necessary

- Conducts pre-job system walk-down as necessary

- Test scheduling/rescheduling as required

- Recording Data Exceptions and support OT notes as required n the OT Test Exception Log (Appendix A-1) and Test Exception Report (Appendix A-2)

- Limit personnel access to work area

2.3.2 Test Engineer (TE) responsibilities:

- The TE shall be qualified as a WRAP facility Design Authority.

- Providing technical support during testing

- Providing programming support during testing

- Forcing data in Programmable Logic Control (-) program during testing

2.3.3. Quality Control (QC) responsibilities:

- QC shall represent the QA department.

- Witnessing and signing steps as identified in OT

- Verifying that the procedure sections were performed correctly, as identified in OT

2.3.4 Maintenance Craft (MC) personnel responsibilities:

- Maintenance Craft shall be qualified per the Collective Bargaining Agreement.

- Providing assistance during OT activities

2.3.5 Operations Personnel (OP) responsibilities:

- Operations personnel shall be WRAP qualified Operators.

- Performing valve manipulations on specified Systems and Test Equipment

- Starting, stopping and operating specified OT equipment

- Controlling and monitoring parameters from OCS, Control Panels and Control Room 


\subsection{Change Control}

2.4.1 OTP and supporting Operating Procedures (OP) administrative or editorial changes required during testing may be accommodated as redline exceptions in the test report, if these changes do not affect operating facility function, performance or safety that could compromise or influence OT data results. Changes to acceptance criteria, requirement changes, or changes to Cautions, Warnings, or any other safety items, and environmental instructions in the OTP or OP shall be approved by the signatories (or their designees) initially approving the respective procedures.

\subsection{Exceptions}

\subsubsection{See Appendix A-1: "TEST EXCEPTIONS LOG" Form}

2.5.1.1 All changes to acceptance criteria, requirement changes, or changes to items and environmental instructions in the OT shall be prepared and approved on an ECN prior to execution of affected step(s).

\subsubsection{See Appendix A-2: "TEST EXCEPTION REPORT" Form}

\subsubsection{All test exceptions shall be resolved or actions documented and} tracked using an approved system (e.g., ECN, JCS or DTS).

\subsection{SAFETY}

WARNING: MATERIAL HANDLING HAZARDS INCLUDE; OVERHEAD/FALLING MATERIALS, PINCH POINTS, ROTATING EQUIPMENT AND RELATED DRUM TRANSFER EQUIPMENT (FORKLIFT, DRUM CARTS AND AGV).

Cranes, forklift, conveyors and transfer carts will be used to move drums or drum assemblies from the discharge conveyor to the TRUPACT container. Other equipment and materials will be moved in and out of the work area to support the assembly/disassembly of the OT. Only authorized personnel (personnel directly involved in the OT) will have access to the various work areas. Other personnel shall observe the permanent or temporary barricades and painted hazard lines while observing the work. Observers may enter the area if authorized by the TD and will comply with safety requirements covered during the pre-job meeting including wearing hard hats when overhead work is in progress. 
Fall hazards, tripping hazards, manual lifting hazards will be present in the area due to the location and materials/equipment used during the OT. These hazards shall be minimized by controlling access to the area and maintaining housekeeping during the OT. Electrical cords, tools, materials and equipment shall be arranged or placed so that personnel have clear walkways or work stations as applicable.

\subsection{RADIATION AND CONTAMINATION CONTROL - FOLLOW APPLICABLE} RWP.

\subsection{QUALITY ASSURANCE}

2.8.1 Quality Assurance witness, holdpoints or verifications are required for calibrated equipment (including torque wrenches, helium leak test system, and weighing devices) in this OT procedure.

2.8.2 The QC Hold Points cited in procedures WRP1-OP -0521, and WRPI-OP0524 shall be completed during implementation of each of those procedures in this OT.

\subsection{GENERAL INFORMATION}

\subsubsection{Active TRUPACT Loadout System interlocks - NONE}

\subsubsection{Stretch Wrapper - EMERGENCY STOP BUTTON}

\subsection{LIMITS AND PRECAUTIONS}

2.10.1 If during performance of this procedure, any of the following conditions are found, immediately notify the assigned TD and TE:

- Any equipment malfunction which could prevent fulfillment of this equipment's functional requirements

- Personnel error or procedural inadequacy which could prevent fulfillment concerning OT procedural requirements

2.10.2 The TD and TE may choose to stop work and place equipment in a safe condition based on the significance of the malfunction, error or inadequacy.

2.10.3 Contact TD and TE for additional instructions if changing plant conditions affect work or delays in work extends beyond (testing) shift.

2.10.4 If any waste is generated during performance of this OT, consult Facility/Plant/Area Hazardous Waste Coordinator for specific instructions to ensure compliance with FDH/WMH and DOE environmental standards, as applicable, for correct disposal. 
2.10.5 Comply with WMH and plant/facility specific lock and tag or over-tagging procedures, as applicable.

2.10.6 Any temporary test equipment or facility configuration changes used to perform this OT shall be documented and resolved on the Test Exception Log and Test Exception Report, respectively. (See item 2.5, "Exceptions" above).

NOTE: All torque requirements are identified in the applicable operating procedures and are to be documented via the procedure requirements.

2.10.7 All Measuring and Test Equipment (MT\&E) used during performance of this OT procedure to collect qualitative data with the exception of "timing devices" (e.g.; stop watch) shall meet the following requirements:

- Be within it's current calibration cycle as evidenced by an affixed calibration label

- Be capable of the desired range

- Have an accuracy (consistent with state-of-the-art limitations) equal to" or greater than the accuracy specified in the OT procedure.

2.10.8 Timing measurements shall be made with commercially available timing devices.

2.10.9 The TD (TE-backup) has overall control conceming testing process and change record authorization for this OT. The TD (TE-backup) is responsible for conducting the test, data collection, and ensuring compliance with all OT requirements.

2.10.10All test data readings are to be taken and recorded for each location where capability exists (i.e., local instrument, LOI, OS).

\subsection{RECORDS}

3.1 This TRUPACT Loadout System OT as well as all completed attachments/appendices will be filed as a permanent test record and managed in accordance with WMH-400, section 1.5.1. 


\section{0 - PREREQUISITES}

NOTE:Unless otherwise specified, prerequisite actions may be performed in any order.

4.1 CONDUCT and DOCUMENT daily pretest briefing on ATTACHMENT 1 for all involved OT personnel. Test Engineer
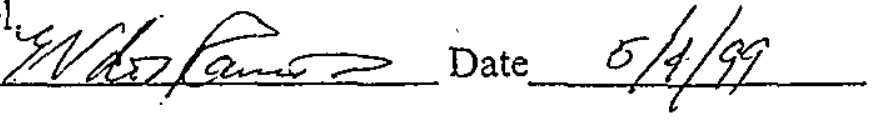

4.2 PERFORM walk-down inspection of system(s) to be tested in this OT.

Test Engineer ndertans Date $5 / 4 / 9)$

4.3 ALIGN system (e.g., valyes) in accordance with Appendix D. Test Engineer interane? Date

4.4 PROVIDE two way portable radio communication (when necessary) between the testing and equipment locations

Test Engineer IIf Date

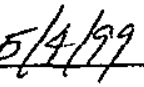

4.5 VERIFY the official OT document and any other OT photocopies to be used during testing are the latest apprgved OT document revision.

Test Engineer Elas hams? Date

4.6 DETERMINE, as appropriate, interface support from other departments/organizations (Maintenance, Safety; RadCon, etc.) and that the necessary support personnel/equipment are available.

Test Engineer Date

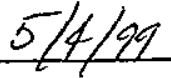

4.7 REVIEW WRAP lock and tag logbook and WALK-DOWN TRUPACT Loadout Systems being tested, and ensure that all components included in the test are controlled by OT personnel.

Test Engineer

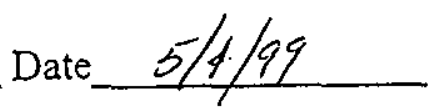


4.8 VERIFY that the training and qualifications records for personnel involved in the OT performance, hafe been docuphented and reviewed. TD Test Manager os Leur Date

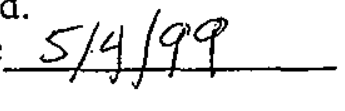

4.9 VERIFY OT.Pakkage documentation for all components, subsystems, and systems within and including the test boundary is ready to work

(ATP/FTP - accepted/closed w/or w/Oesceptions.) TD Test Manager

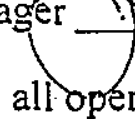
en $(2$, Lat

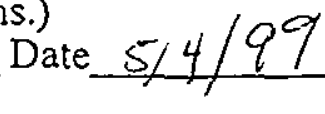

4.10 EVALUATE allopen (ATP/FTP) items (Nonconformance Reports (NCR), and Engineering Change Notices (ECN)) (if any) and VERIFY they do not affect the OT performance. Cog. Engineer

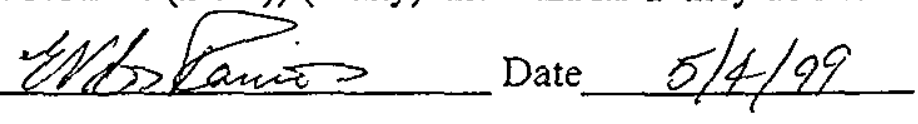

4.11 VERIFY all personnel who will be involved in this OT procedure have provided the required signature verification information in Attachment 1 - Signature Record. Test Engineer

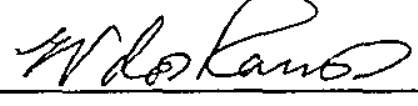
Date

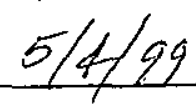

4.12 Equipment/Instruments
4.12.1 See Section 5.0 Procedures for each individual OT activity, and the necessary testing support equipment.

NOTE: During actual operation, a maximum assembly load of 6110 pounds will be administratively set to ensure the heaviest TRUPACT container total-payload weight will not be exceeded. For the purposes of this OT this weight is approximate, and may be exceeded. At no time should the payload exceed 7,000 pounds.
4.12.2 A payload pallet ( 150 pounds) and fourteen (14) -55 gallon test drums filled with water or other medium (approximately 6110 pound test load) will be used to create an individual operational test load.

\subsection{PROCEDURES}

5.1 Loadout System testing activities shall be performed using WRP1-OP-0521, "RECEIVE AND LOAD TRUPACT CONTAINERS", WRP1-OP-0522,". ASSEMBLE AND STRETCH WRAP TRUPACT PAYLOAD", and WRPI-OP-0524, " HELIUM LEAK TEST OF THE TRUPACT-II SHIPPING CONTAINER " attached to this OT procedure.

\subsection{ACCEPTANCE CRITERIA}

6.1 The OT step completion and acceptance will determine whether components/system performance is within design expectations/requirements/specifications. 


\section{ATTACHMENT 2}

\section{TRUPACT SUBSYSTEM - PALLET STRETCH WRAPPER}

(101-SR-05-101)

\subsection{INITIAL CONDITIONS}

1.1 The basis for a satisfactory test is that the WRAP Facility Stretch Wrapper shall demonstrate that the Operational Test can be executed and the performance criteria are achieved. If corrections or adjustments are made, the Operational Test shall be repeated until acceptable results are achieved.

NOTE:1: The Operational Test load is derived from DOE/WIPP 93-1001, Table 3.1. When multiple TRUPACT II containers are to be shipped, DOE/WPP 93-1001, Table 3.2 shall be reviewed to ensure the trailer shipping capacity is not exceeded.

NOTE 2: Where this OT and Operating Procedures conflict, the Operating Procedure will govern.

1.2 Operational Test will demonstrate equipment wrapping for a 14-drum payload. The 14-drum payload shall be comprised of 55-gallon drums (filled with water or other medium totaling approximately 436 pounds per drum) to create a maximum 6,110 pound operational test load. The sequence shall be executed from the Stretch Wrapper Console (101-SR-05-101B) and Stretch Wrapper (Maintenance) Controller (101-SR-05-101A).

\subsection{MATERIALS}

2.1 Fourteen (14) 55-gallon test drums per step 1.2 above, one payload pallet, two reinforcing plates, two slipsheets, and three alignment guide tubes.

2.2 Procedure WRP1-OP-0522, "ASSEMBLE AND STRETCH WRAP TRUPACT PAYLOAD".

3.0 ENSURE OT personnel control the Stretch Wrapper 101-SR-05-101, Controller (101-SR-05-101A), and console (101-SR-05-101B).

TD Signature

TE Signature
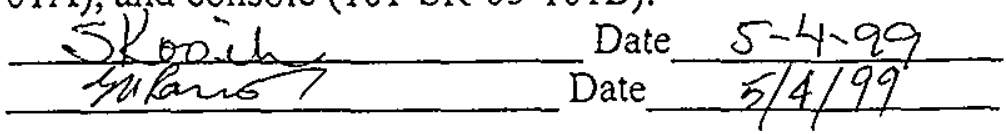

4.0 VERIFY OT personnel control the power supply to Stretch Wrapper 101-SR-05-101.
TD Signature TE Signature Skoouth Date $\frac{5-4-99}{3 / 4 \longdiv { 9 9 }}$ 
J.0 VERIFY SYSTEM GAUGE listed in Appendix B is installed, set to 80-90 psi and responsive.

TD Signature

TE Signature

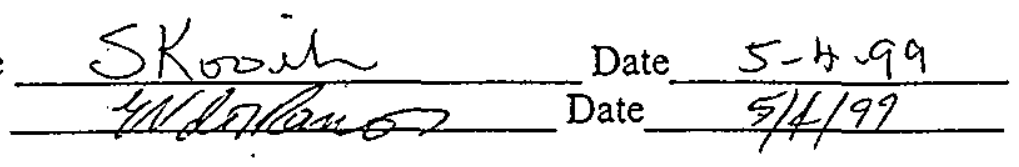

6.0 CYCLE VALVES, listed in Appendix C.

TD Signature

TE Signature

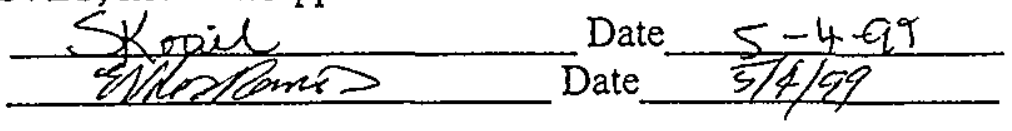

\subsection{CYCLE/ALIGN VALVES}

6.1.1 CYCLE/ADJUST MANUAL VALVE 90 PSI Air System, Apollo 1/2" Pipe/Tube Valve (IA-PCV-114)

\subsubsection{CXCLE BALL VALVE (IA-BV-109)}

6.1.3 RECORD VALVE DEFICIENCIES in Appendix A-1, Test Exception Log TD Signature

TE Signature NA Date

N/A ERR
Date

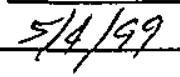

6.1.4 RETURN VALVES to normal operating alignment before testing the system'

TD Signature

TE Signature

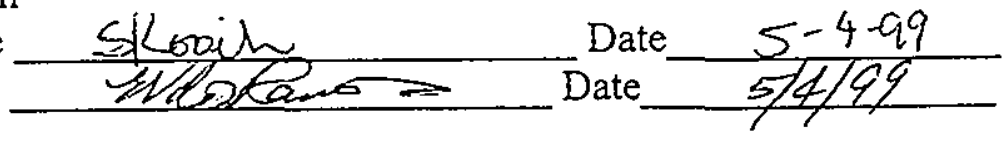

7.0 VERIFY SYSTEM is aligned for Operational Testing in accordance with Attachment $D$ Valve Alignment.

TD Signature

TE Signature

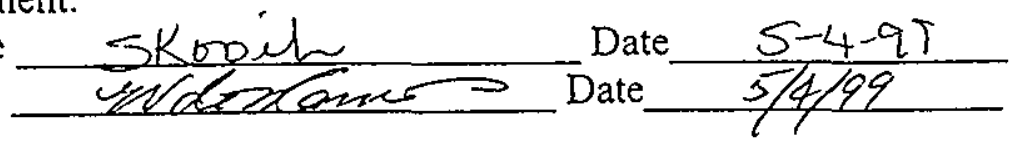

\subsection{STRETCH WRAP MATERIAL}

8.1 VERIFY SYSTEM has an adequate stretch wrap film supply to properly complete testing activities. If the stretch wrap film is inadequate to complete testing activities, go to steps 8.2 and 8.3 .

TD Signature TE Signature

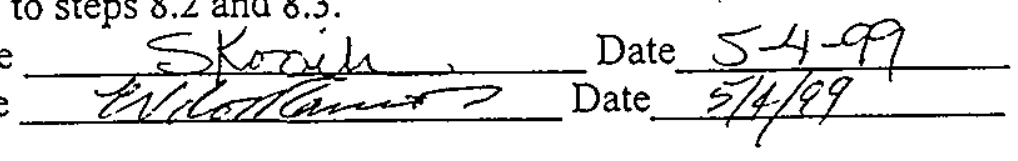

8.2 CONFIRIM OT personnel control, have direct control of system power supply.

TD Signature TE Signature

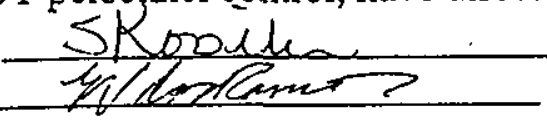
Date Date

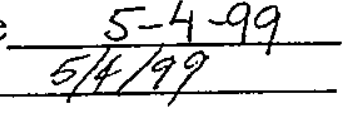


8.3 INSTALL OR CONFIRM NEW STRETCH WRAP FILM (film on spindle, film fed through prestretch film delivery system, film end in turntable slot, machine loaded, and start button initiated). Film holder will start the film automatically after the first time.

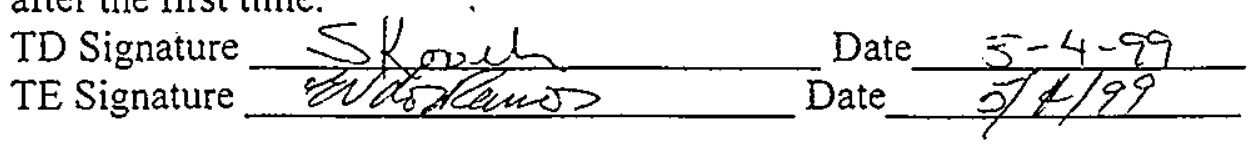

\subsection{OPERATIONAL CHECK LIST - PAYLOAD PALLET}

CAUTION - If the payload pallet is NOT right side up (the ACGLF legs will drive through the lugs and damage the lower spacer of the TRUPACT-II

NOTE - $\quad$ 1. During actual payload assembly, the heaviest seven-drum payload is placed on the bottom pallet.

2. If shipping less than fourteen loaded drums, empty dunnage drums must be used to form the payload while adhering to weight management practices.

3. To allow for pressure changes, the drum must be filtered.

CAUTION - Drum lock ring bolts, if positioned on the outside of the assembly could damage the walls of the TRUPACT-II container.

WARNING - Follow procedure WRP1-OP-0522 and ensure key switch is used to deactivate "START" button when personnel are assembling payload on turntable. IF there is a discrepancy between this OT and WRP1-OP-0522, WRP1-OP-0522 takes precedence.

9.1 PERFORM Procedure WRP1-OP-0522, "ASSEMBLE AND STRETCH WRAP TRUPACT PAYLOAD".

9.1.1 TURN key switch at panel 101-SR-5-101 to "SAFE" position and REMOVE key.

9.1.2 PRESS "START" button and VERIFY stretch wrapper does not start.

TD Signature

TE Signature

$\frac{\text { Skooife }}{\text { Erdozkans Date } \frac{5-4-99}{5 / 4 / 99}}$

9.1.3 VERIFY pallet placement, slipsheet placement, and seven-drum assembly per procedure WRP1-OP-0522.

9.1.4 INSERT key and TURN switch at panel 101-SR-5-101 to "RUN" position.

9.1.5 PRESS "START" button and VERIFY stretch wrapper completes nine (minimum) wraps on upper third of lower drum assembly.

TD Signature

TE Signature

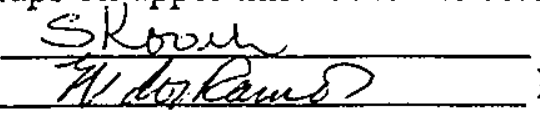
Date

$\frac{5-4-99}{5 / 4 / 99}$


9.1.6 VERIFY turntable comes to a complete stop for placement of the reinforcement sheet on top of the lower drum assembly.

TD Signature SK Solignate Date $5 / 4.99$

9.1.7 TURN key switch at panel 101-SR-5-101 to "SAFE" position and REMOVE key.

9.1.8 PLACE reinforcement sheet on top of the lower drum assembly.

9.1.9 INSERT key and TURN switch at panel 101-SR-5-101 to "RUN" position.

9.1.10 PRESS "START" button and VERIFY additional nine (minimum) wraps on upper third of lower drum assembly.

TD Signature

TE Signature

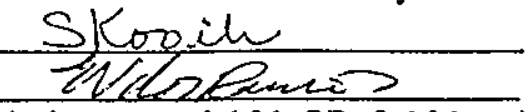

Date $\frac{5-4-99}{574 / 99}$

9.1.11 TURN key switch at panel 101-SR-5-101 to "SAFE" position and REMOVE key.

9.1.12 PLACE slipsheet on top of lower drum assembly and PLACE upper drum assembly.

9.1.13 INSERT key and TURN switch at panel 101-SR-5-101 to "RUN" position.

9.1.14 PRESS "START" button and VERIFY nine (minimum) wraps on upper " third of upper drum assembly.

TD Signature

TE Signature

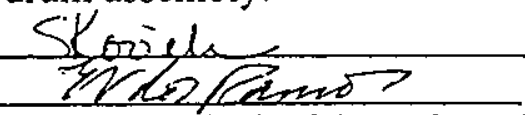

Date $3-4-99$

9.1.15 TURN key switch at panel 101-SR-5-101 to "SAFE" position and REMOVE key.

9.1.16 PLACE reinforcement sheet on top of the upper drum assembly.

9.1.17 INSERT key and TURN switch at panel 101-SR-5-101 to "RUN" position.

9.1.18 PRESS "START" button and VERIFY additional nine (minimum) wraps on upper third of upper drum assembly.

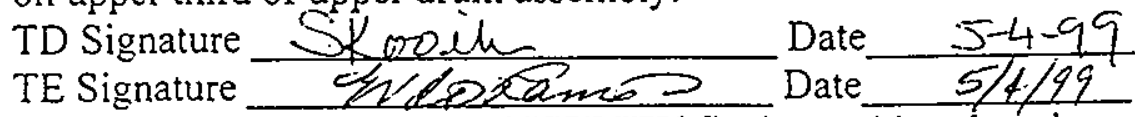

9.1.19 PRESS "START" button and VERIFY final wrap(s) and cutting of stretch

$\begin{array}{cl}\text { Test exception wrap. } \\ \text { 00 } & \text { TD Signature }\end{array}$

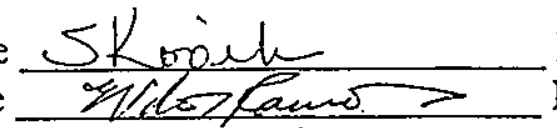

Date $\frac{5-6-99}{576 / 99}$

9.1.20 VERIFY 14-drum assembly ejects onto accumulation conveyor.

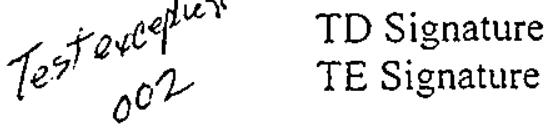
TE Signature Date $\frac{5-4-99}{5 / 4 / 99}$

10.0 SECURE STRETCH WRAPPER from the Operational Test

TD Signature

TE Signature SKooil Udertaner? Date

$\frac{5-6-99}{376 / 99}$

11.0 Stretch Wrapper (TRUPACT SUBSYSTEM) testing is complete.
TD Signature
TE Signature

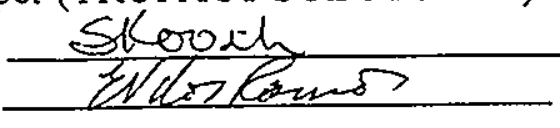 Date Date $\frac{5-6-99}{5 / 6 / 99}$ 


\section{ATTACHMENT 3}

TRUPACT SUBSYSTEM - TRUPACT ACCUMULATION (GRAVITY) CONVEYOR

$$
\text { (101-CV-05-104) }
$$

\subsection{INITIAL CONDITIONS}

1.1 The basis for a satisfactory test is that the WRAP TRUPACT Accumulation (Gravity) Conveyor shall demonstrate that the Operational Test can be executed and acceptable results are achieved. If corrections or adjustments are made, the Operational Test shall be repeated until acceptable results are achieved.

1.2 Operational Test will demonstrate equipment ability to transfer the 14-drum payload from the stretch wrapper and stop the payload at the bridge crane pick-up . location at the end of the accumulation conveyor.

\subsection{MATERIALS}

2.1 Stretch Wrapper (Attachment 2) payload pallets consisting of:

One payload pallet, Fourteen 55-gallon drums, two plastic slipsheets, two reinforcing plates and three alignment guide tubes.

3.0 ENSURE OT personnel control the TRUPACT Accumulation (Gravity) Conveyor 101-CV-05-104 at both the TRUPACT Lift Fixture Pickup and TRUPACT End Stop . locations.

TD Signature

TE Signature

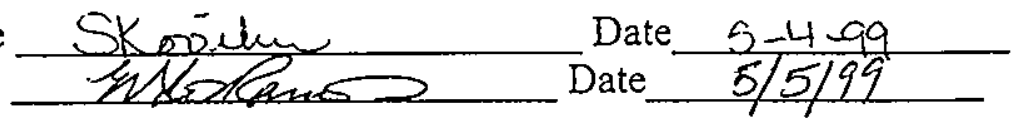

4.0 OPERATIONAL CHECK LIST - PAYLOAD PALLET

4.1 CONFIRM PLACEMENT OF PAYLOAD PALLET on stretch wrapper turntable.

4.2 CONFIRM PLACEMENT OF SLIPSHEET on top of payload pallet. 
4.3 CONFIRM PLACEMENT OF "LOWER" SEVEN 55-gallon (water or other medium) TEST DRUMS

NOTE: During actual operation, the heaviest 7-drum assembly will be placed on the bottom.

\subsubsection{CONFIRM INITIAL 55-GALLON DRUM ALIGNMENT (lower level) is} "tangent" to the mechanical blue block start position indicator.

\subsection{CONFIRM PLACEMENT OF "MIDDLE” PLASTIC SLIPSHEET AND REINFORCING PLATE.}

4.5 CONFIRII PLACEMENT OF "UPPER" SEVEN 55-gallon (water or other medium) TEST DRUMS.

4.5.1 CONFIRM INITIAL 55-GALLON DRUM ALIGNMENT (upper level) is "tangent" to the mechanical blue block start position indicator.

4.6 CONFIRM PLACEMENT OF THREE (3) ALIGNMENT GUIDE TUBES three (3) different locations.

4.7 CONFIRM PLACEMENT OF "TOP" PLASTIC REINFORCING PLATE.

\subsection{OPERATIONAL TEST - PAYLOAD PALLET}

5.1 VERIFY THE ALIGNMENT OF TRUPACT CONVEYOR RAILS are checked by moving an empty aluminum payload pallet down the conveyor while manually controlling its velocity.
TD Signature
TE Signature indovit
indents Date $\frac{5-6-99}{5 / 6 / 97}$

5.2 VERIFY POWERED TURNTABLE CONVEYOR automatically discharges the 14-drum payload pallet to the TRUPACT Accumulation (Gravity) Conveyor. The payload discharge operation shall be regulated by a photoelectric sensor mounted on the TRUPACT Accumulation (Gravity) Conveyor at a point allowing payload pallet staging.

TD Signature TE Signature

\begin{tabular}{|c|c|}
\hline Skooulu & Date $5-4-99$ \\
\hline $4 \operatorname{los} \operatorname{cou} x$ & Date $5 / 5199$ \\
\hline
\end{tabular}


5.3 VERIFY AUTOMATIC PALLET STOP OPERATION is checked with light weight pallets (EMPTY test drums) by loosening the arm return springs to the minimum tension required to retum the arms to the upright position using payload pallet.

TD Signature TE Signature

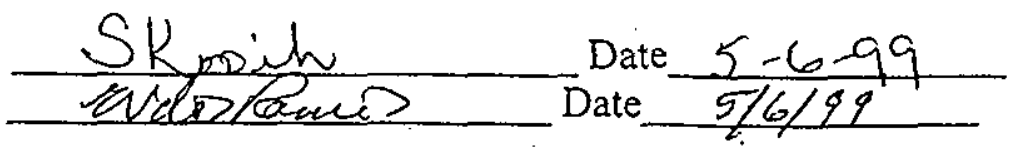

This completes the "INITIAL" TRUPACT Accumulation (Gravity) Conveyor operations test.

WARNING - Make sure lever is in fully raised position prior to testing stop.

6.0 VERIFY AUTOMATIC PALLET STOP OPERATION. Re-tension the arm return springs prior to further testing using "FULLY" loaded test drums on payload pallet.

Payload Pallet velocity (FPS): 6min $10 \mathrm{sec}, 39^{\prime} 8^{\prime \prime} \quad 107 \mathrm{ft} / \mathrm{s}$

TD Signature

TE Signature
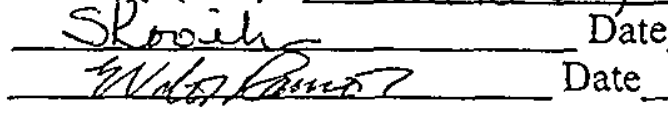
Date

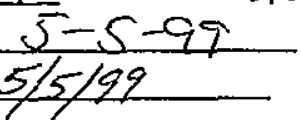

IF REQUESTED by the TD or TE, repeat paragraph 6.0.

Payload Pallet velocity (FPS):

TD Signature

TE Signature $N A$ $N A \quad$ Date NA $\because \mathbb{R}$ Date $5 / 6 / 99$

7.0 SECURE STRETCH WRAPPER from the Operational Test

TD Signature

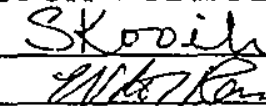

TE Signature Date Date $\frac{5-6-99}{5 / 6 / 99}$

8.0 TRUPACT Accumulation (Gravity) Conveyor (TRUPACT SUBSYSTEM) testing is complete.

TD Signature

TE Signature

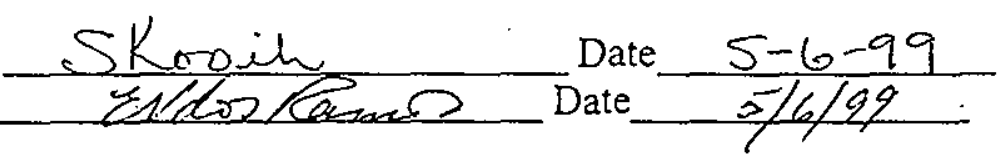




\section{ATTACHIMENT 4}

\section{TRUPACT SUBSYSTEM - BRIDGE CRANE}

$(101-C R-05-103)$

\subsection{INITIAL CONDITIONS}

1.1 The basis for a satisfactory test is that the WRAP Bridge Crane shall demonstrate that the Operational Test can be executed and acceptable results are achieved. If corrections or adjustments are made, the Operational Test shall be repeated until acceptable results are achieved.

1.2 Operational Test will demonstrate the bridge crane's ability to use the load cell, ACGLF, and associated lift legs to lift a 14-drum payload and place it in a TRUPACT II container. The 14-drum payload shall be comprised of 55-gallon drums (filled with water or other medium totaling approximately 436 pounds per drum) to create a maximum 6,110 pound operational test load. The sequence shall be executed from the bridge crane "hardwire" pendant and remote control pendant.

\subsection{MATERIALS}

2.1 TRUPACT Accumulation (Gravity) Conveyor, one payload assembly consisting of one payload pallet, 14 test drums, plastic slipsheets, alignment guide tubes and reinforcing plates, one (1) TRUPACT container with one each inner and outer lid support stands and adjustable center of gravity lifting fixture with support stands. The TRUPACT bridge crane will use a calibrated dynamometer (load cell) with the adjustable center of gravity lifting fixture (ACGLF) for handling the 14 test drums on each payload pallet. The payload pallets will be loaded into the TRUPACT container. The bridge crane will be used for removing and installing the outer and inner containment vessel (ICV \& OCV) lids.

3.0 CONFIRM Annual P/M, Monthly P/M are current and no outstanding deficiencies.

VERIFY no "out of service" tags are present at the bridge crane controller.

TE Signature: Date:

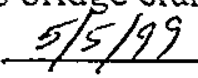

4.0 VERIFY OT personnel control the Bridge Crane pendant and remote pendant.

TD Signature:

TE Signature:

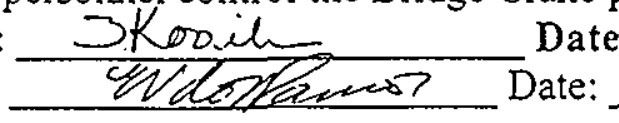
Date: $\frac{5-5-99}{575799}$

5.0 CONFIRM POWER SUPPLY from Motor Control Cabinet (MCC) MCC-05-101, is activated to supply system power. 


\subsection{OPERATIONAL CHECK LIST}

NOTE - Previous approved testing activities (ATP/FTP) may be indicated in the OT step signature space using initials/date and past test document references with a date.

6.1 CONFIRM one (1) loaded payload pallet secured on the TRUPACT Accumulation (Gravity) Conveyor. TD Signature: TE Signature: Date: Date:

6.2 PERFORM and DOCUMENT daily bridge crane pre-operational check sheet (Attachment 4A). TD Signature: TE Signature:

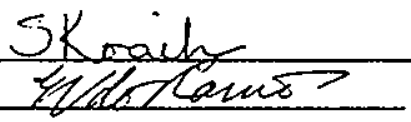
Date: Date:

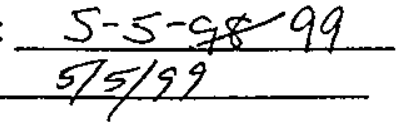

7.0 This completes the Bridge Crane operations test. AFTER the loaded payload pallet begins initial testing activities associated with Attachment 3, "TRUPACT Accumulation (Gravity) " Conveyor".

8.0 SECURE BRIDGE CRANE (from the Operational Test.

TD Signature TE Signature

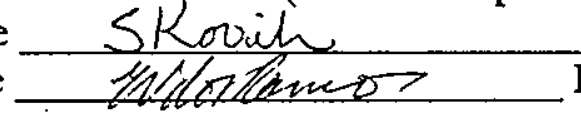
Date $\frac{5-5-99}{5 / 5 / 99}$

9.0 Bridge Crane (TRUPACT SUBSYSTEM) is considered closed.

TD Signature TE Signature

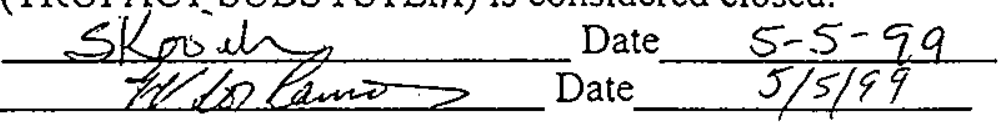




\section{ATTACHMENTT 4A}

\section{- Daily Bridge Crane Inspection Checklist -}

\section{CAUTION}

This crane is NOT equipped with slow-down or end-of-travel limit switches for trolley and bridge motions. DONOT allow equipment to continue operation if producing abnormal noises or other signs of malfunction. DONOT allow equipment to impact obstacles or adjacent structures.

DONOT run into limits or end stops at full speed.

DONOT lower hoist beyond the point of two wraps of rope at each anchorage on the drum.

DO NiOT override, bypass, remove or defeat any control, safety device or circuit.

Report any deficiencies or probable cause of early failure for corrective action. Any equipment found to be defective shall be tagged with an UNSAFE EQUIPMENT, DANGER - DO NOT OPERATE or CAUTION tag as required until properly repaired.

\begin{tabular}{|c|c|c|c|}
\hline \multirow{2}{*}{$\begin{array}{c}\text { CHECKPOINT } \\
\text { Indicate a }(\checkmark) \text { in the appropriate } \\
\text { condition column block. }\end{array}$} & \multicolumn{2}{|c|}{ CONDITION } & \multirow{2}{*}{$\begin{array}{c}\text { COMMENTS \& } \\
\text { OBSERVATIONS } \\
.\end{array}$} \\
\hline & OK & $\mathrm{BAD}$ & \\
\hline $\begin{array}{l}\text { Hoisting Ropes/Cables - Check hoisting ropes for obvious visual damage } \\
\text { which may be a hazard. }\end{array}$ & & & \\
\hline $\begin{array}{l}\text { Hook and Latch - Check hook and latch for obvious damage. Check latch for } \\
\text { proper engagement. }\end{array}$ & & & \\
\hline $\begin{array}{l}\text { Control Station - Check pushbutton control for smooth switch operation and } \\
\text { legible motion indicators. }\end{array}$ & & & \\
\hline $\begin{array}{l}\text { Lower Hoist Limit - Without load on hook, slowly lower load block and check } \\
\text { for low limit to stop hoist motion. Use full speed until near limit. }\end{array}$ & & & \\
\hline $\begin{array}{l}\text { Upper Hoist Limit - Without load on hook, slowly raise load block and check } \\
\text { for upper limit to stop hoist motion. Use full speed until near limit. }\end{array}$ & & & \\
\hline $\begin{array}{l}\text { Bridge Motion - With hook raised, bridge crane along runway within } 10 \text { feet of } \\
\text { both end stops. Run at all speeds and check for smooth operation and braking. }\end{array}$ & & & \\
\hline $\begin{array}{l}\text { Trolley Motion - With hook raised, rin trolley within } S \text { feet of both end stops. } \\
\text { Run at all speeds and check for smooth operation and braking. }\end{array}$ & & & \\
\hline $\begin{array}{l}\text { Emergency Stop - DEPRESS "STOP" (red) pushbutton to halt all crane } \\
\text { motions. Reset using "START" button. }\end{array}$ & & & \\
\hline
\end{tabular}

Additional Information:

Inspected By:
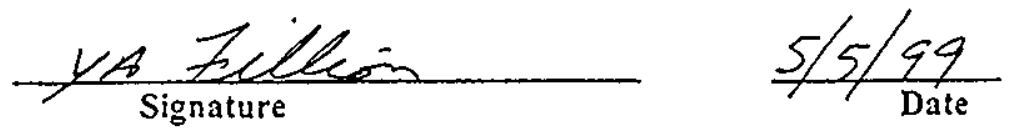


\section{ATTACHMENT 5 \\ TRUPACT SUBSYSTEM - ADJUSTABLE CENTER OF GRAVITY LIFTING FIXTURE \\ (GOVERNMENT FURNISHED EQUIPMENT)}

(100-CR-05-104)

\subsection{INITIAL CONDITIONS}

1.1 The basis for a satisfactory test is that the WRAP Adjustable Center of Gravity Lifting Fixture (ACGLF) shall demonstrate that the Operational Test can be executed and acceptable results are achieved. If corrections or adjustments are made, the Operational Test shall be repeated until acceptable results are achieved.

1.2 Operational Test will demonstrate the ability of the ACGLF to lift, level, and place a 14-drum payload intó a TRUPACT II container. The 14-drum payload shall be comprised of 55-gallon drums (filled with water or other medium totaling approximately 436 pounds per drum) to create a maximum 6,110 pound operational test load. The sequence shall be executed from the bridge crane.

\subsection{MATERIALS}

2.1 TRUPACT Accumulation (Gravity) Conveyor, one (1) payload assembly consisting of one payload pallet, 14 test drums, plastic slipsheets, alignment guide tubes, reinforcing plates, one (1) TRUPACT II container with two (2) inner/outer lid support stands and ACGLF with an equipment support stand.

3.0 VERIFY OT personnel control the ACGLF.

TD Signature

TE Signature

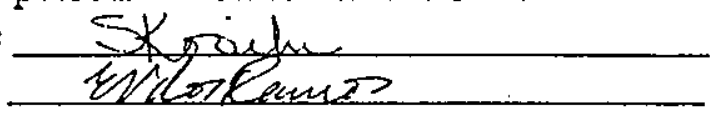

Date $\frac{5-5-99}{5 / 5 / 99}$

4.0 CONFIRM POWER SUPPLY from Motor Control Cabinet (MCC) 101-MC-05-102, PP-05-102, BRKR 20, is activated to supply system power.

\subsection{OPERATIONAL CHECK LIST}

NOTE - Previous approved testing activities (ATP/FTP) will be indicated in the OT step signature space using initials/date and past test document references with date.

5.1 CONFIRI a minimum of one (1) LOADED PAYLOAD PALLET is secured on the TRUPACT Accumulation (Gravity) Conveyor. 
5.2 CONFIRM the 5-TON BRIDGE CRANE is available for performing this test procedure.

\subsection{CONFIRM THAT A CURRENT CALIBRATED AND CERTIFIED}

DYNAMOMETER (load cell) with a minimum of 15,000-pound full-scale range is available for performing this test procedure.

5.4 VERIFY a load test inspection verification and acceptance has been completed (Review PM/sticker information).
TD Signature
TE Signature

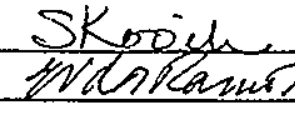 Date $\frac{5-5-99}{5 / 5 / 99}$

\subsection{LOAD TEST REQUIREMENTS}

6.1 VERIFY and RECORD applicable dynamometer data.

MAKE: Dynalink

MODEL: $m S I-7200$

$\mathrm{S} / \mathrm{N}: 70465$

RANGE: limited calilration for $20,000 \mathrm{lb}$ lbs.

CURRENT CALIBRATION DATE: 2/2/99

ZERO READING: \& lbs.

TD Signature SKovert Date $\epsilon_{5}-5-99$

TE Signature Date $5 / 5 / 99$

NOTE: The lift fixture is equipped with two sets of removable legs ("LONG". and "SHORT").

6.2 VERIFY AND RECORD the free hanging weight of the lift fixture with "LONG" lift legs and dynamometer installed, using the bridge crane.

Lift Fixture Weight, using "LONG" legs:

TD Signature

TE Signature

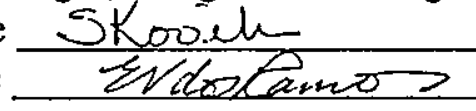

$$
2660
$$
Date Date lbs.

6.3 VERIFY AND RECORD The Free Hanging Weight Of The Lift Fixture with "SHORT" lift legs and dynamometer installed, using the bridge crane.

Lift Fixture Weight, using "SHORT" legs:

TD Signature TE Signature
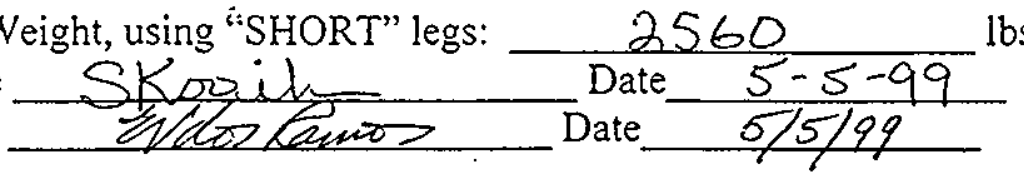

6.4 PERFORM Daily ACGLF Inspection Checklist (Attachment 5A) 
6.5 VERIFY LOAD TEST INSPECTION and lift fixture acceptance (Review $\mathrm{PM}$ /sticker information).
TD Signature
TE Signature

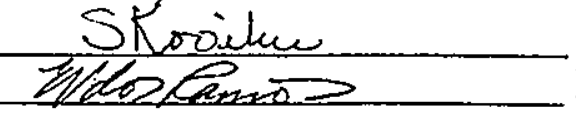
Date $\frac{5-5-99}{5 / 5 / 99}$

6.6 MANEUVER THE BRIDGE CRANE TO THE TRUPACT ACCUMULATION (GRAVITY) CONVEYOR LOAD PICKUP STATION. The lifting fixture shall be lowered onto the payload test pallet through the guide tubes, until the three (3) receptacles are inserted into the payload test pallet lift lugs.

TD Signature

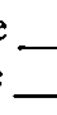$$
\text { OKoail }
$$

Date Date $\frac{5-5-q 9}{5 / 5 / 49}$

\section{CAUTION - DO NOT PROCEED WITH ADDITIONAL TESTING ACTIVITIES, UNLESS STEP 6.6 CONDITIONS ARE MET.}

6.7 VERIFY from an operator console that the operator operates one control in each hand (two [2] controls) to activate the lifting leg unlock operation. The lifting legs shall be rotated to the lock position using the lift fixture three independent electrical actuators. Three (3) indicator lights will identify the engagement rotation for each of the three (3) lifting legs.
TD Signature
TE Signature

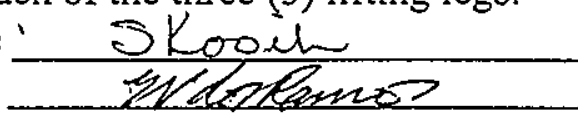 Date $\frac{5-5-99}{5 / 5 / 99}$

CAUTION - Payload weight exceeding 7,000 pounds require evaluation prior to lifting.

NOTE: Proper balancing and leveling correction can be adjusted by actuating the gear motors to revolve the balancing weights until the tilt angle in both planes indicates less than $+/-0.5$ degrees.

6.8 VERIFY PAYLOAD PALLET IS LIFTED, approximately three (3) or more inches above the floor surface and the tilt angle in two places is monitored from the control console.

6.9 RECORD weight of test payload. $\frac{6000}{\text { TD Signature iS Kovich }}$ Date TE Signature INdeos Lawo Date $5-5-99$ $\begin{array}{r}8660 \\ -2660 \\ \hline 6000\end{array}$

7.0 ACGLF (TRUPACT SUBSYSTEM) testing is complete. The payload pallet is ready for further lifting and loading into the TRUPACT II containment vessel.

TD Signature

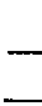

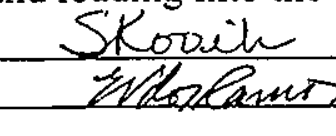
Date $\frac{5-5-99}{5 / 5 / 99}$ 


\section{ATTACHMENT $5 \dot{A}$}

\section{- Daily ACGLF Inspection Checklist -}

\section{CAUTION}

DONOT lift ACGLF until bridge crane and load cell daily inspection is completed.

DONOT operate ACGLF until controls are warmed-up for a minimum of ten minutes.

DONOT load ACGLF unless all pins, keepers, shackles or locks are fully engaged.

DONOT lif ACGLF unless countenveights are balanced.

DO NOT allow equipment to continue operation if producing abnormal noises or other signs of malfunction.

DONOT allow equipment to impact obstacles or adjacent structures.

DONOT overtide, bypass, remove or defeat any control, safety device or circuit.

Report any deficiencies or probable cause of early failure for corrective action. Any equipment found to be defective shall be tagged with an UNSAFE EQUIPMENT, DANGER - DO NOT OPERATE or CAUTION tag as required until properly repaired.

\section{CHECKPOINT \\ Indicate $a(\checkmark)$ in the appropriate \\ condition column block.}




\section{ATTACHMENT 6 \\ TRUPACT SUBSYSTEM - TRUPACT II (CONTAINER) \\ (GOVERNMENT FURNISHED EQUIPMENT)}

\subsection{INITIAL CONDITIONS}

1.1 The basis for a satisfactory test is that Operations shall perform WRP1-OP-521 (Use 5-Ton bridge crane, a calibrated dynamometer and the WRAP Adjustable Center of Gravity Lifting Fixture (ACGLF) to place a 14-drum payload inside the TRUPACT II container, reinstall the ICV and OCV lids, and COGEMA shall perform WRP1-OP-0524 to leak test the TRUPACT II container to simulate readiness to ship. If corrections or adjustments are made, the Operational Test shall be repeated until acceptable results are achieved.

NOTE - The test load may exceed 6110 pounds if approved and documented as a test exception by the TE.

1.2 Operational Test will demonstrate integrity of a 14-drum payload. The 14-drum payload shall be comprised of 55-gallon drums (filled with water or other medium totaling approximately 436 pounds per drum) to create a maximum 6,110 pound operational test load. The sequence shall be executed from the bridge crane.

\subsection{MATERIAL}

2.1 One "loaded" payload pallet; ACGLF/lifting legs (short/long) with an equipment support storage stand; bridge crane; one (1) TRUPACT II container with one each inner and outer lid support storage stands; special hand tools for lock ring locking bolt removal/turning inner/outer lid rings; vent port tools; weather seal band; dynamometer/load cell; and helium gas.

3.0 VERIFY OT personnel control the use of and access to the TRUPACT II

TD Signature

TE Signature

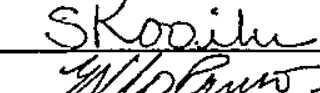
Entopanos Date Date $\frac{5-5-99}{5 / 5 / 99}$

\subsection{OPERATIONAL CHECK LIST}

NOTE - Previous approved testing activities (ATP/FTP) will be indicated in the OT step signature space using initials/date and past test document references with a date.

4.1 CONFIRM ONE (1) TRUPACT II CONTAINER with one each inner and outer lid support storage stands are available and located in the WRAP loadout area. 
4.2 CONFIRM SPECIAL HAND TOOLS are available and located on the wrap loadout area supporting TRUPACT II lock ring locking bolt removal, turning inner-outer lid rings and associated vent port tools.

4.3 CONFIRM sliding the ocv lid closure area weather seal band down on the outer vessel below the elevation of the OCV vent port cover.

5.0 PERFORM procedure WRP1-OP-0521, "RECEIVE AND LOAD TRUPACT CONTAINERS".

TD Signature

TE Signature

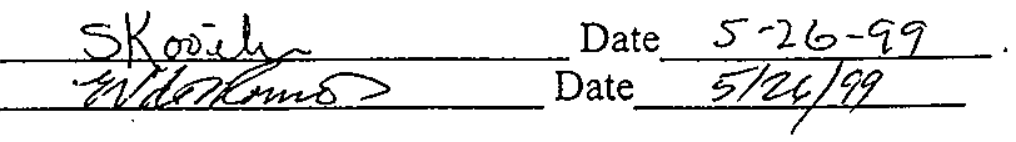

6.0 PERFORM procedure WRP1-OP-0524, "HELIUM LEAK TEST OF THE TRUPACT-II SHIPPING CONTAINER"

TD Signature

TE Signature

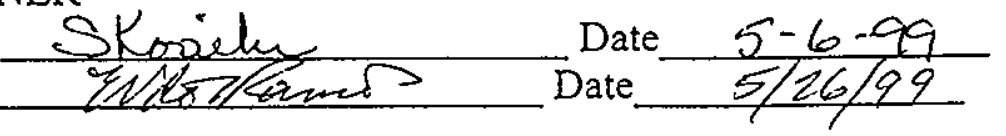

7.0 TRUPACT II container (TRUPACT subsystem) is considered closed.

TD Signature

TE Signature

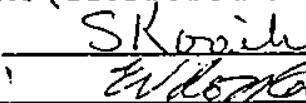

Date Date

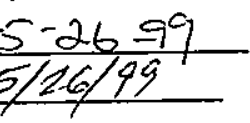




\section{ATTACHMENT 7 \\ TRUPACT SUBSYSTEM - TRUPACT LOADING PLATFORM}

(100-PF-05-101 and 102)

\subsection{INITIAL CONDITIONS}

1.1 The basis for a satisfactory test is that the WRAP TRUPACT Loading Platforms shall demonstrate that the Operational Test can be executed and the acceptable results are achieved. If corrections or adjustments are made, the Operational Test shall be repeated until acceptable results are achieved.

\subsection{MATERIALS}

2.1 One TRUPACT II container.

3.0 VERIFY OT personnel control access and control panels for the TRUPACT loadout platforms.

TD Signature

TE Signature

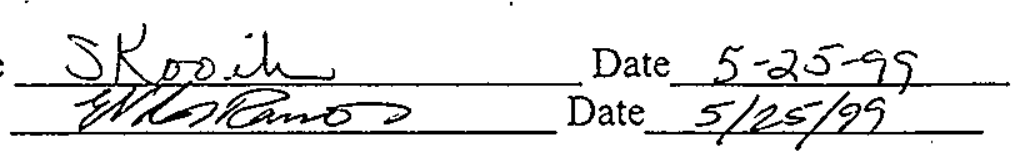

\subsection{OPERATIONAL CHECK LIST}

NOTE - Previous approved testing activities (ATP/FTP) will be indicated in the OT step signature space using initials/date and past test document references with a date.

4.1 CONFIRM ONE TRUPACT II CONTAINER positioned in the WRAP loadout area.

4.2 CONFIRM LOADOUT PLATFORM HOIST RAISING, LOWERING AND LIMIT SWITCHES/STOPS FUNCTION.

Observe each loadout platform operation for abrupt movements. 


\section{S.0 OPERATIONAL TEST}

5.1 VERIFY loadout platform clearance and operation of pivoting sections, with TRUPACT II container in place.

Platform Number 100-PF-05-102A

TD Signature St $00 . \mathrm{il}$

TE Signature

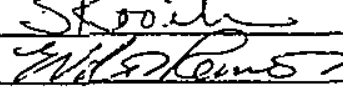
Date Date

$\frac{5-2579}{5 / 25 / 49}$

Platform Number 100-PF-05-102B
TD Signature
TE Signature Skooih Indostanos Date $\frac{5-25-99}{5 / 25 / 99}$

5.2 VERIFY loadout platform hoist raising, lowering and limit switches/stops function, with TRUPACT II container in place.

100-PF-05-102A

TD Signature

TE Signature

Skovih Eldostemon? Date Date

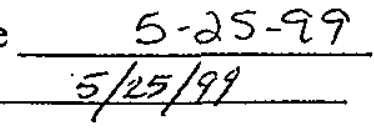

100-PF-05-102B

TD Signature

TE Signature

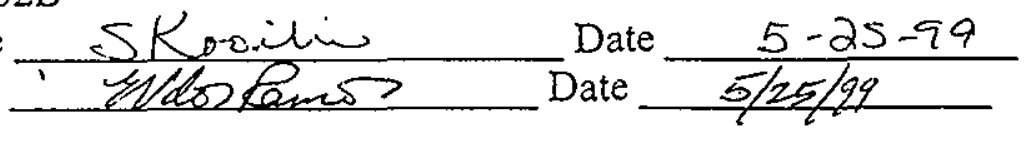

5.3 CHECK each loadout platform operation for abrupt movements.

PLATFORM NUMBER 100-PF-05-101A

TD Signature

TE Signature

$\frac{\text { Skovilu }}{\text { Eldentens Date } \frac{5-25-99}{5 / 25 / 99}}$

PLATFORM NUMBER 100-PF-05-101B

TD Signature

TE Signature

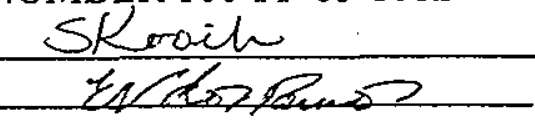
Date $5-25-97$ Date $5 / 25 / 99$...

PLATFORM NUMBER 100-PF-05-102A

TD Signature

TE Signature

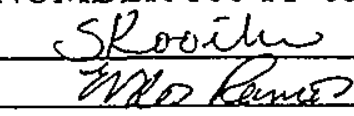
Date $\frac{5-25-97}{5 / 25 / 99}$ 
PLATFORM NUMBER 100-PF-05-102B

TD Signature

TE Signature

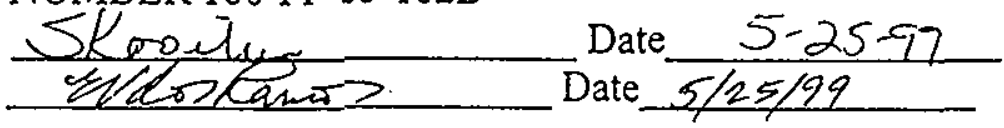

5.4 CHECK screw actuator limit switches function.

100-PF-05-101A

TD Signature

TE Signature

Skojehe Date $\frac{5-25-99}{5 / 25 / 99}$

100-PF-05-101B

TD Signature SKovein

TE Signature isdartaners Date Date $\frac{5-25-99}{5 / 25 / 99}$

VERIFY sliding platforms manual operation with actuators disengaged. Operation shall demonstrate freedom of movement with no binding or racking.

PLATFORM NUMBER 100-PF-05-101A

TD Signature

TE Signature

$$
\text { SKooih }
$$

Date $5-25-9$

PLATFORM NUMBER 100-PF-05-101B

TD Signature Skroitu

TE Signature Date Date $\quad 5-25-99$ Date

5.6 VERIFY control panel operation. Platform shall respond to button actuatations and appropriate lamps shall illuminate.

100-PF-05-102A

TD Signature

TE Signature

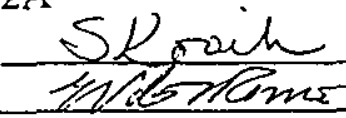
Date $5-25-99$ Date $5 / 25 / 99$

100-PF-05-102B

TD Signature

TE Signature

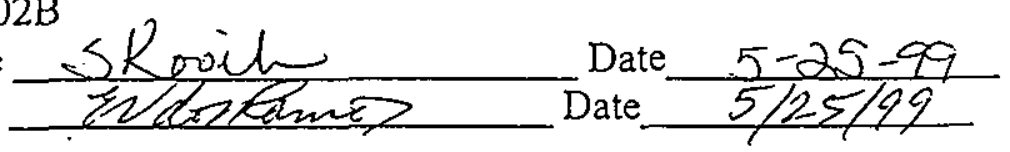

5.10 VERIFY remote mounted audible alarm and amber flashing beacon operation.

100-PF-05-102A

TD Signature

TE Signature

Skovilu inazano Date Date $\frac{5-25-99}{5 / 25 / 99}$

100-PF-05-102B

TD Signature

TE Signature

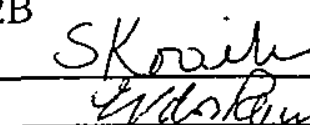


7.0 Loading Platform (TRUPACT SUBSYSTEM) testing is complete.

TD Signature Skovilie Date $5-25-97$ 
APPENDIX A-1

\begin{tabular}{|c|c|c|c|c|}
\hline \multicolumn{5}{|c|}{ TEST EXCEPTION LOG } \\
\hline $\mathrm{TE} \#$ & DATE & DESCRIPTION & DISPOSITIONED & $\begin{array}{c}\text { DATE } \\
\text { CLOSED }\end{array}$ \\
\hline & & & & \\
\hline & & & & \\
\hline & & & & \\
\hline & & & & \\
\hline & & & & \\
\hline & & & & \\
\hline & & & & \\
\hline & & & & \\
\hline & & & & \\
\hline & & & & \\
\hline
\end{tabular}




\section{APPENDIX A-2}

TEST EXCEPTION REPORT

\begin{tabular}{|l|l|l|}
\hline $\begin{array}{c}\text { TEST PROCEDURE NO. \& } \\
\text { SECTION: }\end{array}$ & TEST NAME: & T.E. NUMBER: \\
\hline
\end{tabular}

\section{DESCRIPTION OF PROBLEM:}

ORIGNATOR:

ORG.

DATE:

DISPOSITION:
IMPACT ON TESTING: LHOLD FOR RESOLUTION ICONTINUE

PIC:

DATE:

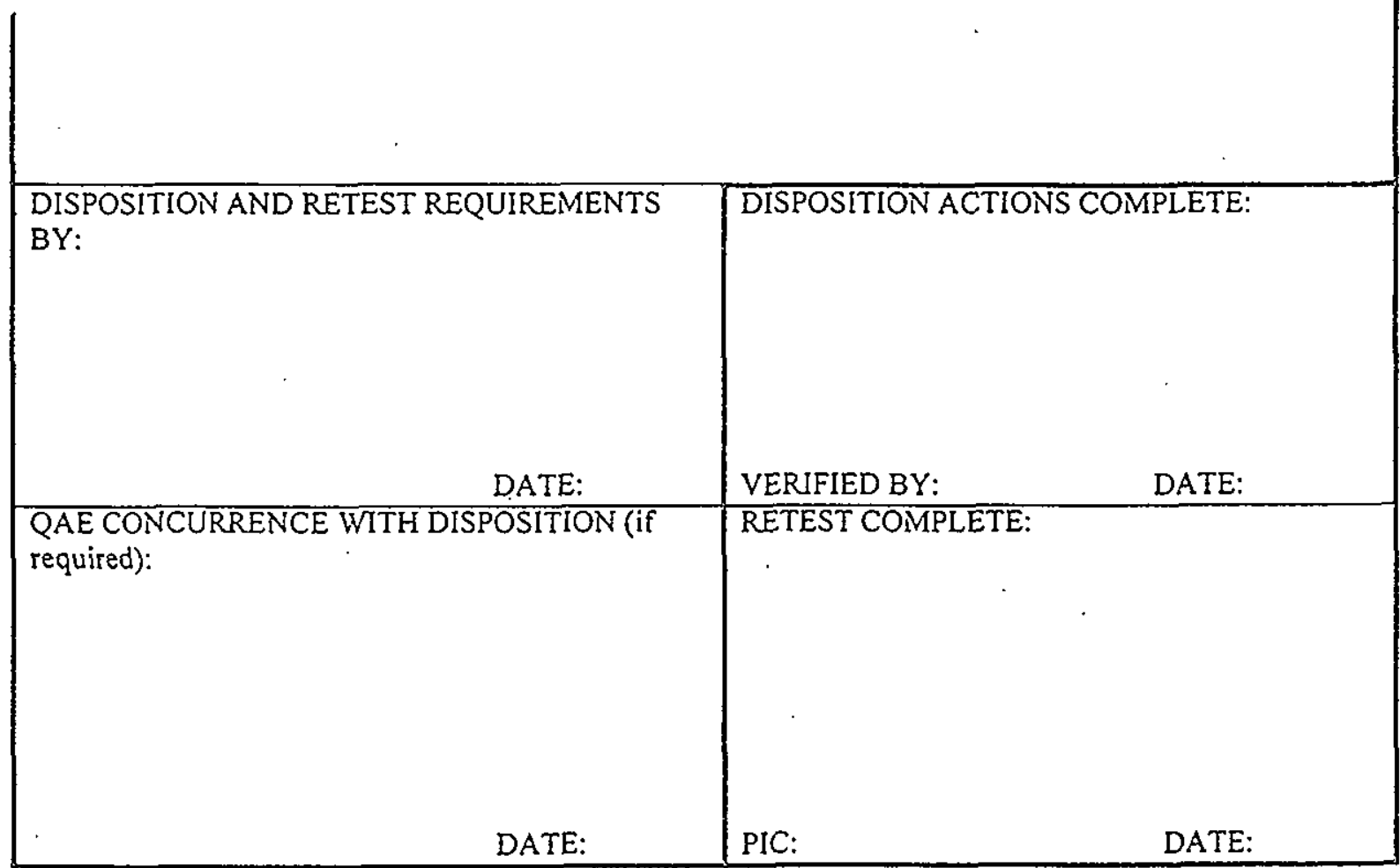




\section{APPENDIX B}

\section{LIST OF INSTRUMENTATION REQUIRING CALIBRATION VERIFICATION}

\begin{tabular}{|c|c|c|c|}
\hline \hline EQUIPMENT NO. & $\begin{array}{c}\text { FUNCTIONAL } \\
\text { DESCRIPTION }\end{array}$ & SIGNATURE & DATE/TIME \\
\hline \hline $\begin{array}{c}\text { IA-PI-115 } \\
\text { (Indication Only) }\end{array}$ & $\begin{array}{l}\text { STRETCH WRAPPER } \\
\text { PRESSURE INDICATOR }\end{array}$ & SKoOil & $5-4-9.9$ \\
\hline & & & \\
\hline & & & \\
\hline & & & \\
\hline
\end{tabular}




\section{APPENDIX C}

\section{MANUAL VALVE CYCLE LIST}

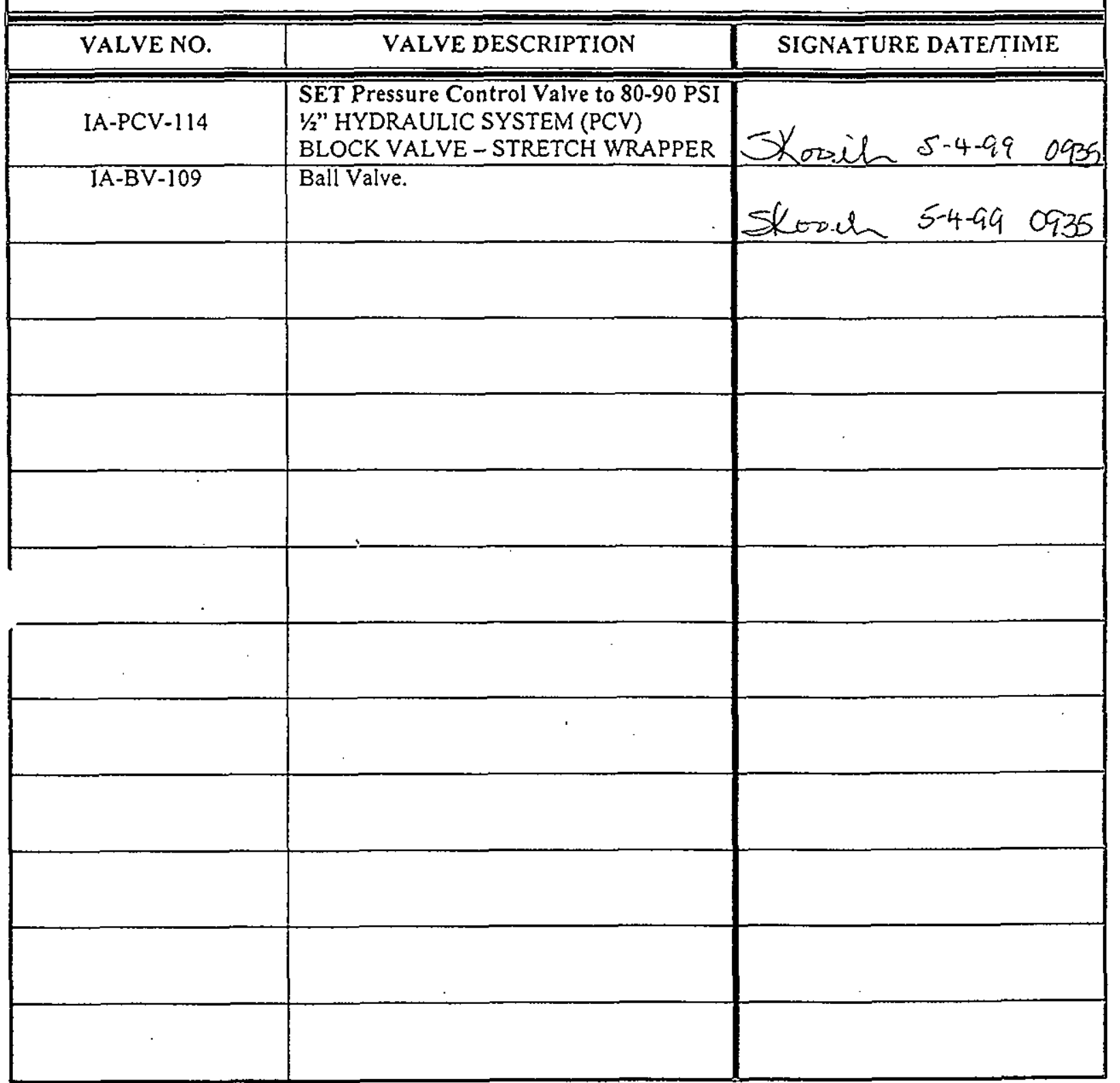


Project W-026, WRAP

INF -3919

Operational Testing - TRUPACT Loadout System

Page 35

APPENDIX A-1

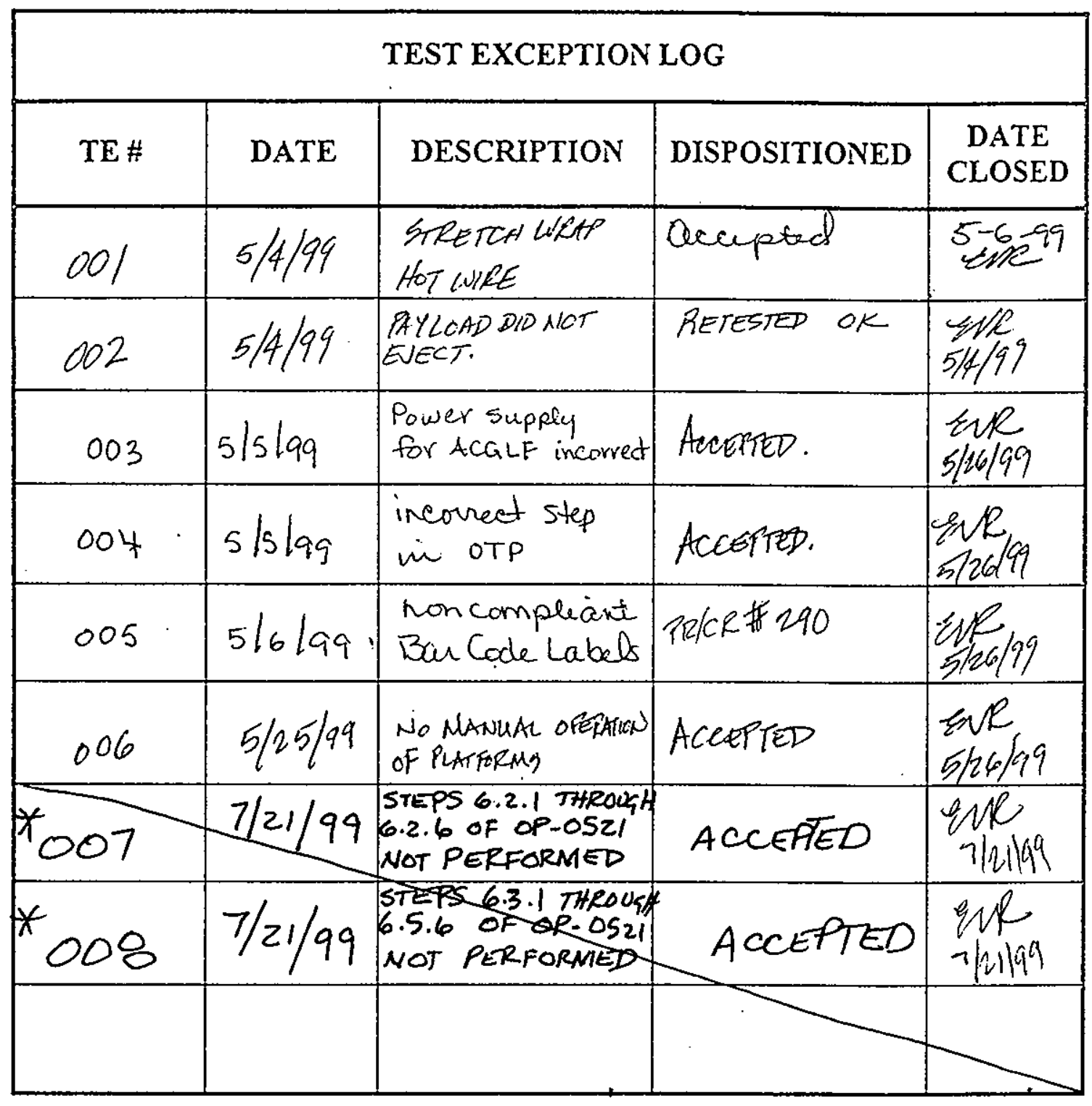

* test exceptions 007 t do 8 were IDENTIFIED AFTER COMPLETION OF THE DTP AND ARE INCLUDED FOR DOCUMENTATION PURPOSES. 


\section{APPENDIX A-2}

\section{TEST EXCEPTION REPORT}

TEST PROCEDURE NO. \& Q.1.19

SECTION: ATTACH. 2

DESCRIPTION OF PROBLEM:

at the end of the wrapping operation, the hot wire arm moved to cut the plastic, but the wire did not hat or did not heat up enough to cut tho wire

TEST NAME:

RuET Stretch Wrapper
T.E. NUMBER:

$\infty 1$

ORG. Epuations

DATE: $\quad 5-4-99$ IMPACT ON TESTING: DHOLD FOR
RESOLUTION X'CONTINUE

PIC: SKoowh

DISPOSITION:

DATE: $5-5-99$

\section{REQUEST MAINTENANCE RDJUST POT SETTING. RETEST TO VERIFY FILM CUTTING OPERATION.}

DISPOSITION AND RETEST REQUIREMENTS BY:

$N / A$
DATE: $5 / 6 / 99$ QAE CONCURRENCE WTTH DISPOSITION (if required):
DISPOSITION ACTIONS COMPLETE:

VERIFIED BY: 96 ODuL DATE: $5-6-99$ RETEST COMPLETE:<smiles>CC(C)(C)[Ge]([Ge])=[Ge]</smiles>

DATE: $\quad$ PIC: Sllooul DATE: $5-6=9$ 
Project W-026, WRAP

HNF-3919

Operational Testing - TRUPACT Loadout System

Rev. 0

Page 37

APPENDIX A-2

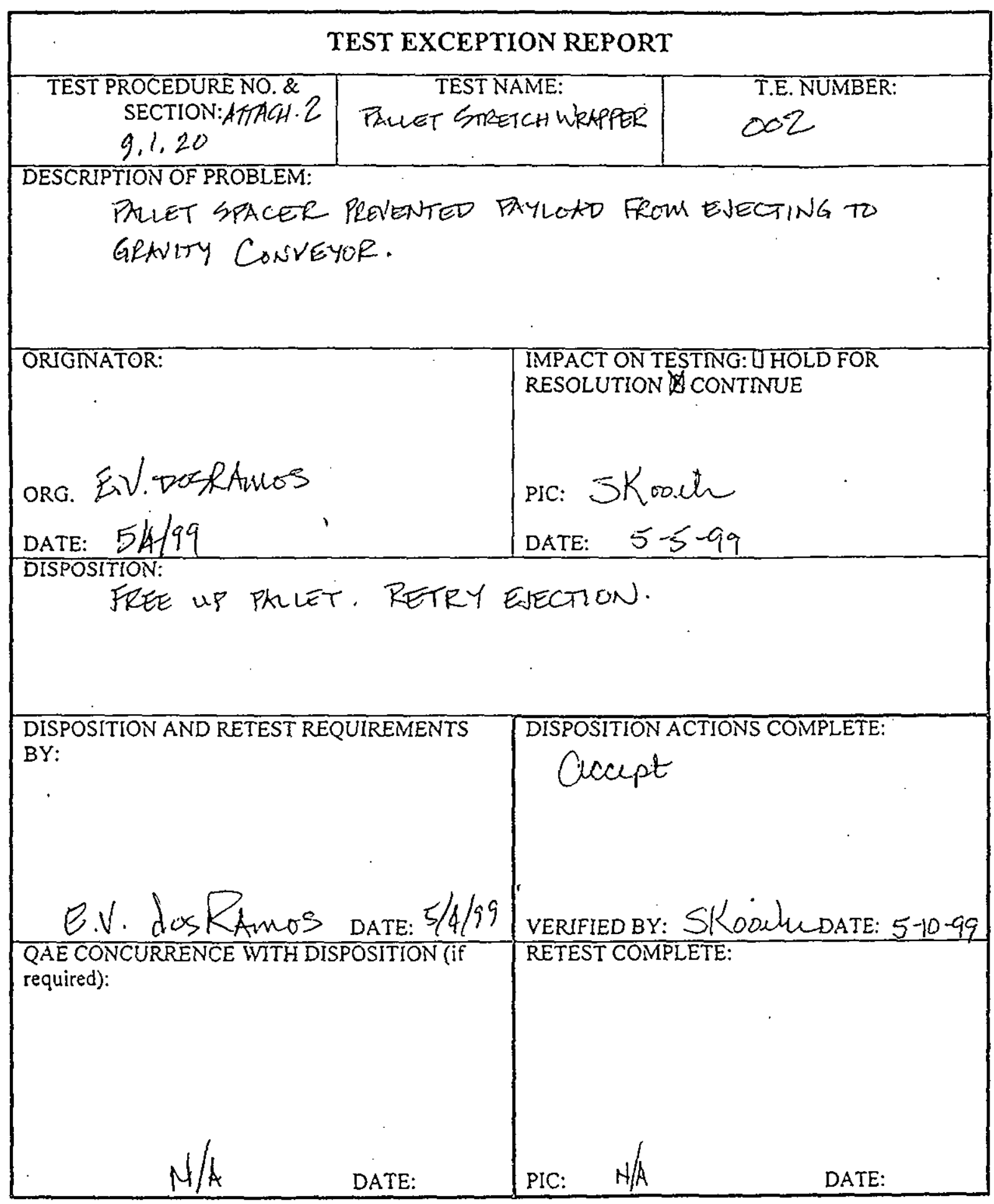


Project W-026, WRAP

HNF-3919

Operational Testing - TRUPACT Loadout System

Rev. 0

Page 38

APPENDIX A-2

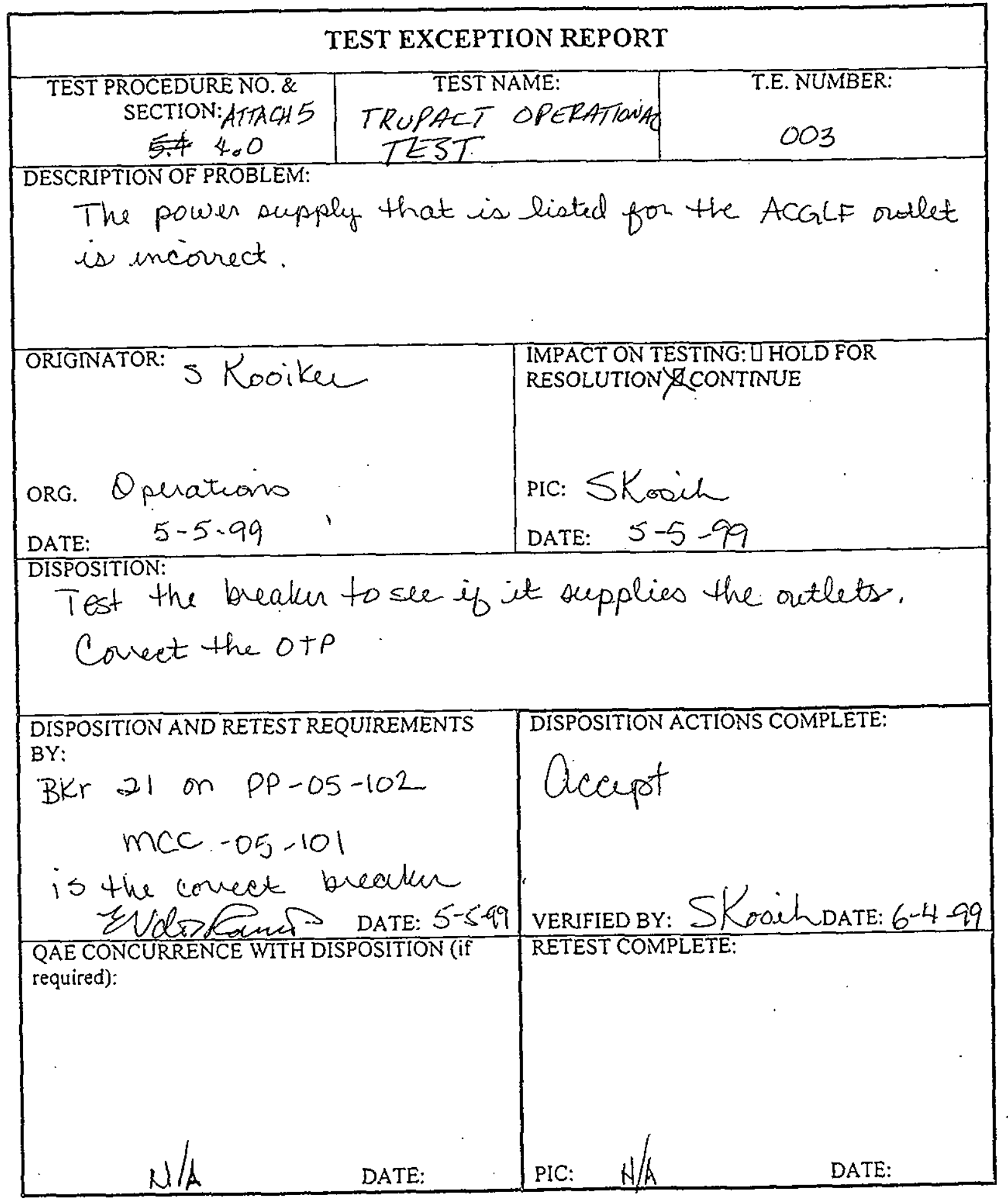




\section{APPENDIX A-2}

\section{TEST EXCEPTION REPORT}

\begin{tabular}{|c|c|c|}
\hline $\begin{array}{c}\text { TEST PROCEDURE NO. \& } \\
\text { SECTION: }\end{array}$ & TEST NAME: & T.E. NUMBER: \\
AHt6 Step 4.3 & TRUPACT OPERATIONR & 04 \\
\hline DESCRIPTIONOF PROBLEM: & TEST & TES \\
\hline
\end{tabular}

DESCRIPTION OF PROBLEM:

The step is not valid when using a training TRUPAC.

ORIGNATOR: 5 Kooiku:

ORG. Opuationo

DATE: $\quad 5-5-99$

DISPOSITION:

delcte the step from the OTP

DISPOSITION AND RETEST REQUIREMENTS

BY:

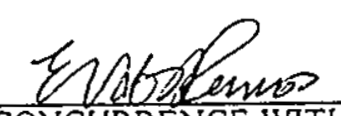

DATE: 5/25/99 VERIFIED BY:SK ooih QAE CONCURRENCE WITH DISPOSITION (if required):
DISPOSITION ACTIONS COMPLETE:

complete RETEST COMPLETE:

DATE: $6-9-99$

IMPACT ON TESTING: U HOLD FOR RESOLUTION RCONTINUE

PIC: SKooic DATE: $\quad 5-5-97$ 
APPENDIX A-2

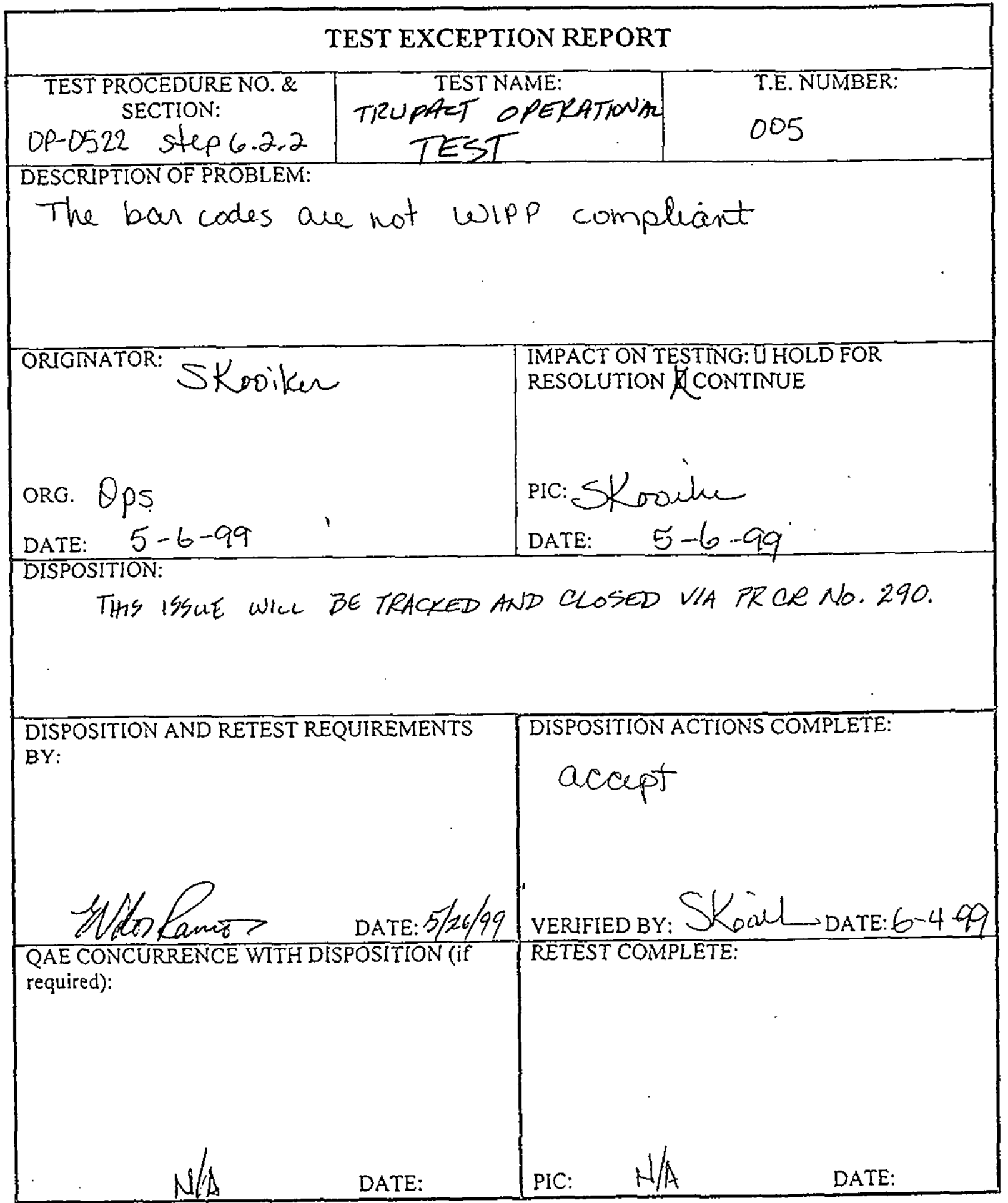


Project W-026, WRAP

HIE - 3919

Rev. 0

Page 42

Operational Testing - TRUPACT Loadout System

APPENDIX A-2

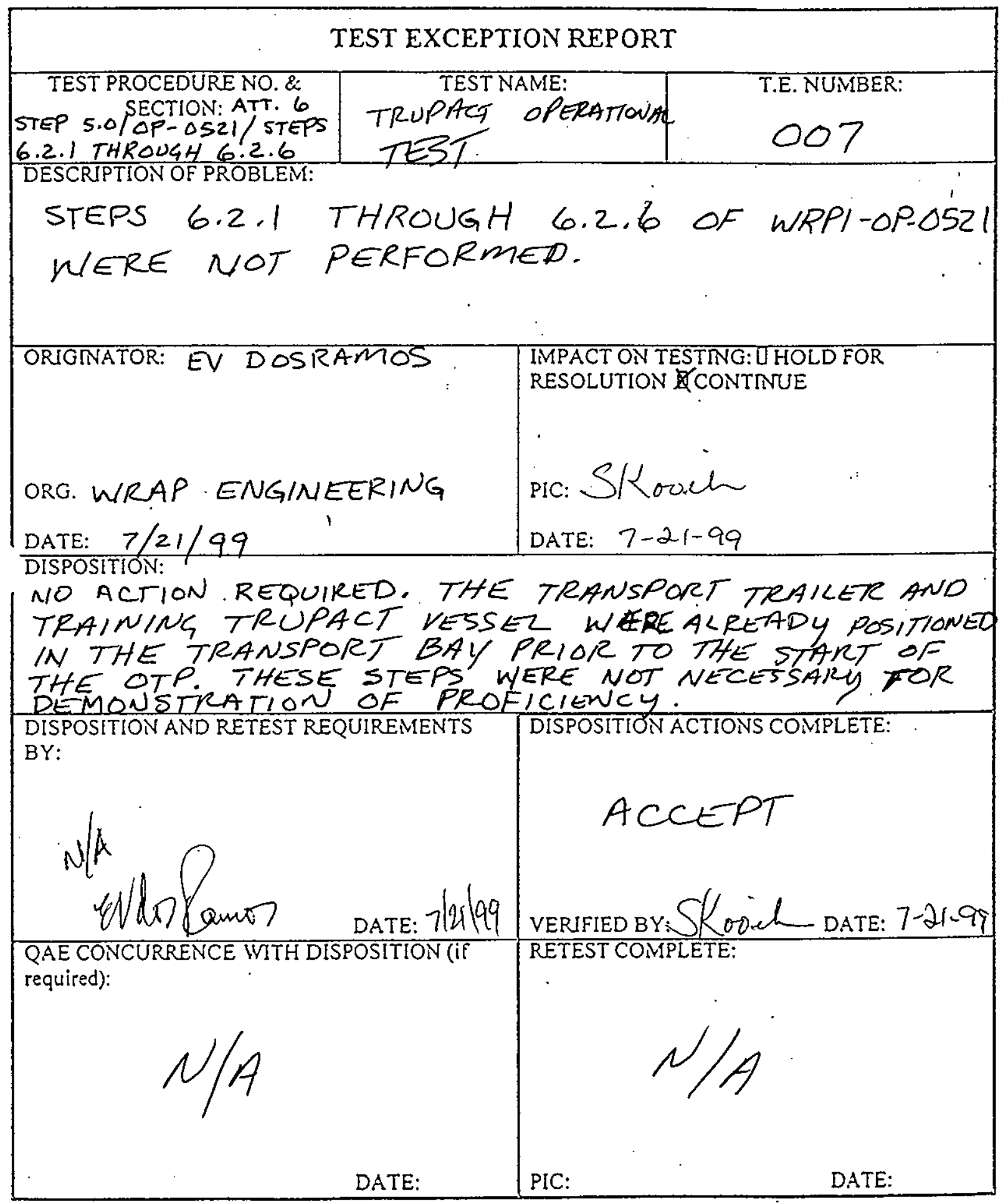


Project W-026, WRAP

FINF-3919

Rev. 0

Operational Testing - TRUPACT Loadout System

Page 43

APPENDIX A-2

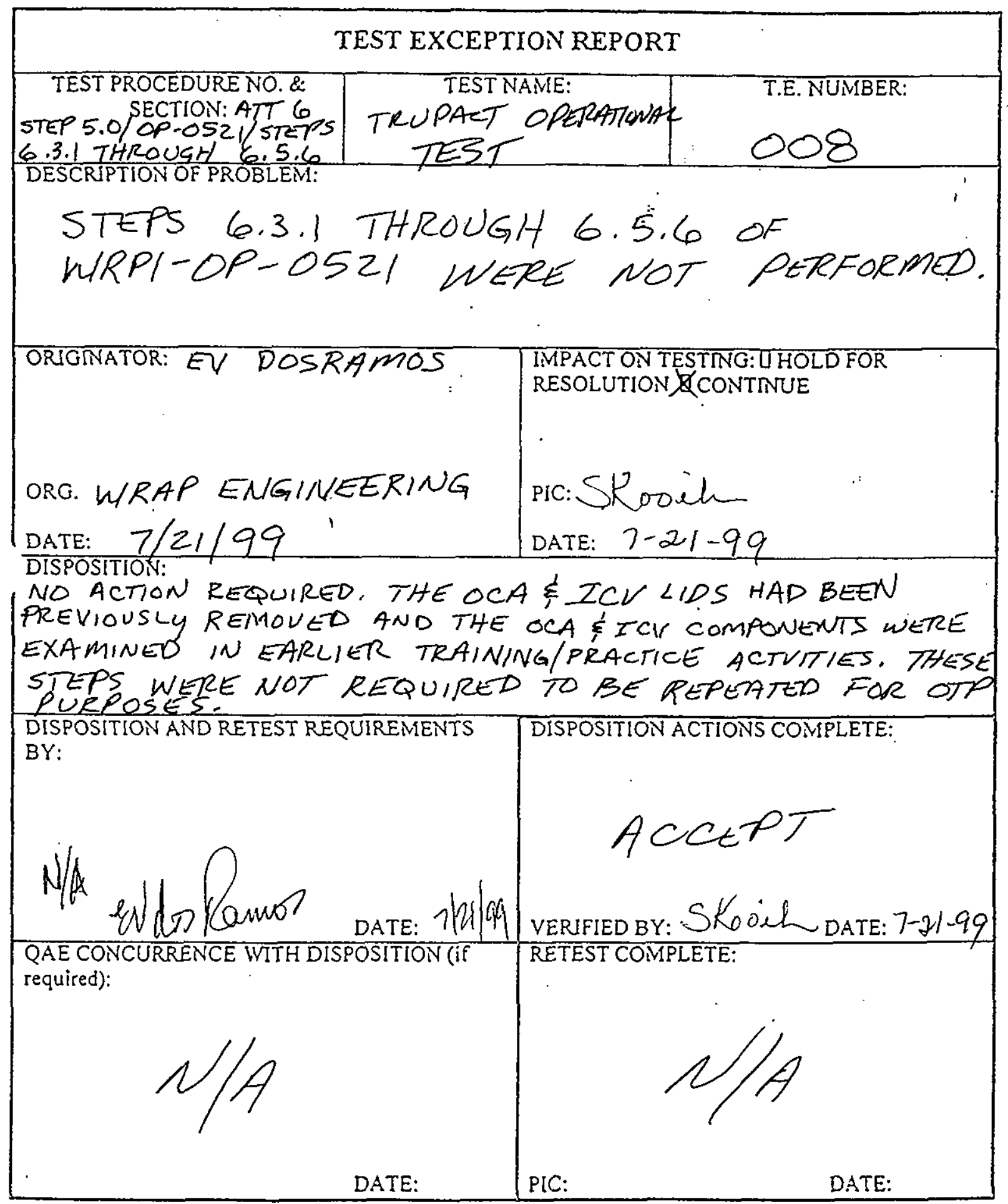




\section{COMPLETED ATTENDANCE ROSTERS AND DATA AND SIGNATURE SHEETS}

NOTE:

THE REMAINING PAGES OF THIS DOCUMENT (43 THROUGH 66) ARE COPIES OF THE COMPLETED ATTENDANCE ROSTERS AND DATA AND SIGNATURE SHEETS. 
PRE-JOB SAFETY MEETING

ATTENDANCE ROSTER
HING - 3919

Rev. 0

Page 45

$5-6-99$

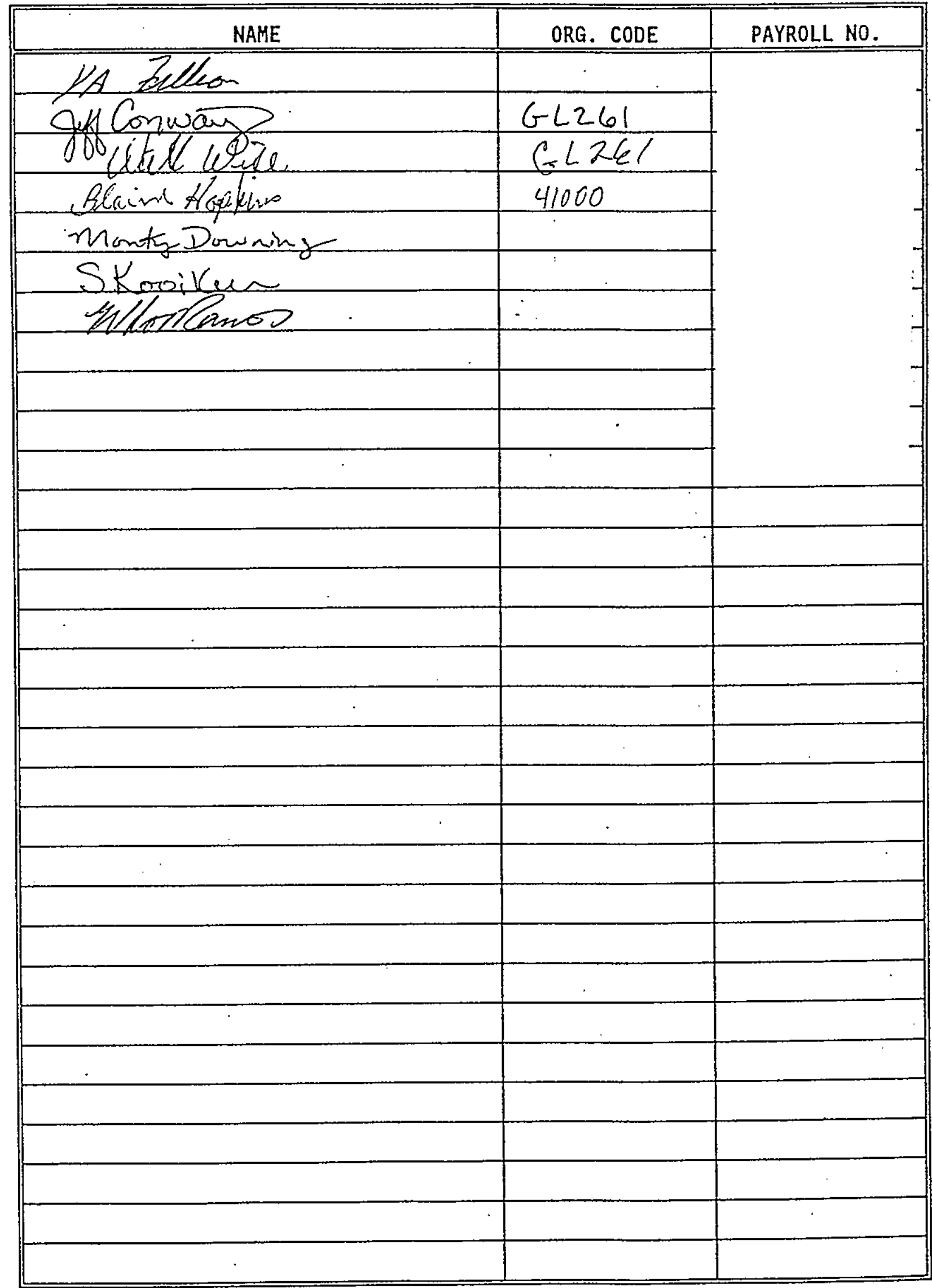

HPDATAIPREJOB 


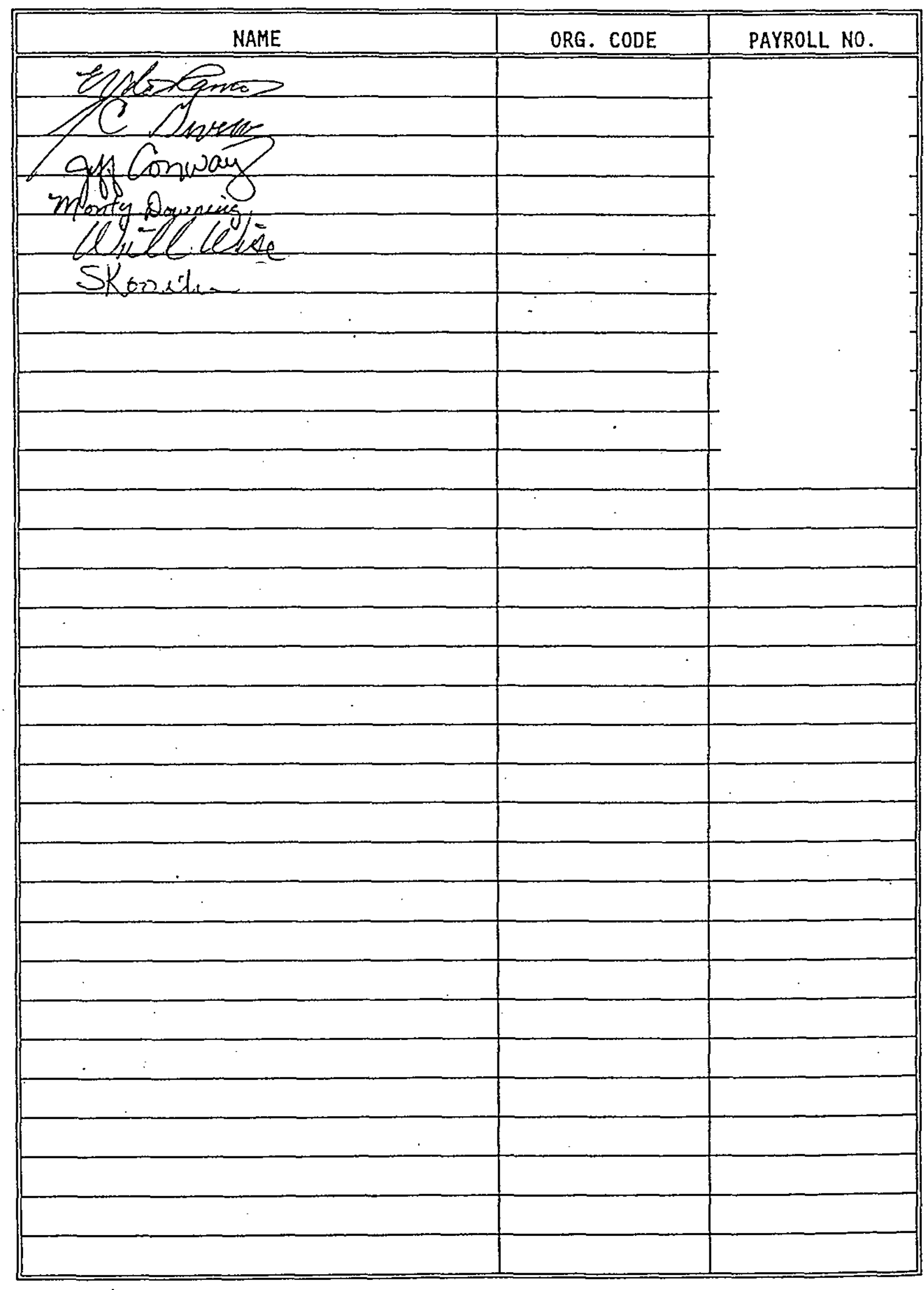


HNF - 3919

Rev. 0

AJHA 10: W1-47

Facility: Wi

Pre-Job Safety Meeting Form

Page 47

Job Description

Receive and load TRUPACTII containers. AJHA to serve as base job hazard analysis for procedure WRP1-OP-0521

Pre-job for orp

Work Title

Receivelload TRUPACTII

Page 2

Date

$5-3-99$

Work Number

$2336 \mathrm{~W}$ room 101

ATTENDANCE ROSTER (Continued)

\begin{tabular}{|c|c|c|}
\hline Name & $:$ Org. Code & Payroll No. \\
\hline ERuARDO $V$ DOSRAMOS &. &
\end{tabular}

MLEHEL F. BRICKEY SR

DANIEL L. CHASE

J. Sykeles Givens

MejortR Meyer Michaed

Susame Qooiker 
Project W-026, WRAP

FNF -3919

Rev. 0

Page 48

Operational Testing - TRUPACT Loadout System

\section{TRUPACT-II DRUM WEIGHTS}

\begin{tabular}{|c|c|}
\hline DRUM NUMBER & WEIGHT (LBS) \\
\hline 1 & 420 \\
\hline 2 & 340 \\
\hline 3 & 420 \\
\hline 4 & 420 \\
\hline 5 & 400 \\
\hline 6 & 440 \\
\hline 7 & 420 \\
\hline 9 & 420 \\
\hline 10 & 380 \\
\hline 11 & 420 \\
\hline 12 & 440 \\
\hline 13 & 420 \\
\hline 14 & 420 \\
\hline \multicolumn{2}{|c|}{} \\
\hline TOTAL & 420 \\
\hline
\end{tabular}




\section{WASTE RECEIVING AND PROCESSING (WRAP) FACILITY \\ RECEIVE AND LOAD TRUPACT-II CONTAINERS \\ WRP1-OP-0521}

Rev. 0

Page 49

Rev/Change A-1

Printed: May 5, 1999

PAGE 33 of 43

ATTACHMENT I - TRUPACT-II Main 0-Ring Exchange Form

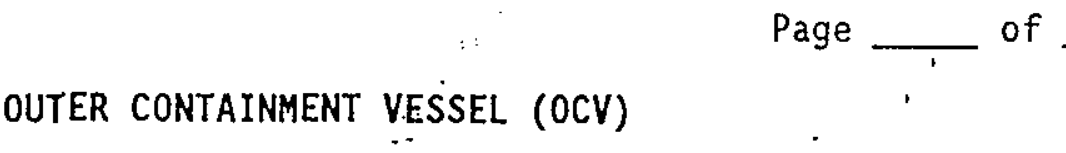

TRUPACT-II Serial \#:

OCV

Upper 0-Ring PO. Number \& Date Installed:

Lower 0-Ring PO. Number \& Date Installed:

Spare Upper 0-Ring P.O. Number:

Spare Lower 0-Ring P.0. Number:

Upper 0-Ring Exchanged:

Lower 0-Ring Exchanged:

VESEL (OCV)

Upper 0-Ring Exchanged:

Lower 0-Ring Exchanged:

(Name \& Date)

(Name \& Date)

Upper 0-Ring Exchanged:

Lower 0-Ring Exchanged:

(Name \& Date)

(Name \& Date)

Upper 0-Ring Exchanged:

Lower 0-Ring Exchanged

(Name \& Date)

(Name \& Date)

Upper 0-Ring Exchanged:

Lower 0-Ring Exchanged:

(Name \& Date)

(Name \& Date)

Upper Q-Ring Exchanged:

Loyer 0-Ring Exchanged:

(Name \& Date)

(Name \& Date)

See Page 35 for Instructions 


\section{WRP1-OP-0521}

ATTACHMENT I - TRUPACT-II Main 0-Ring Exchange Form

INNER CONTAINMENT VESSEL (ICV)

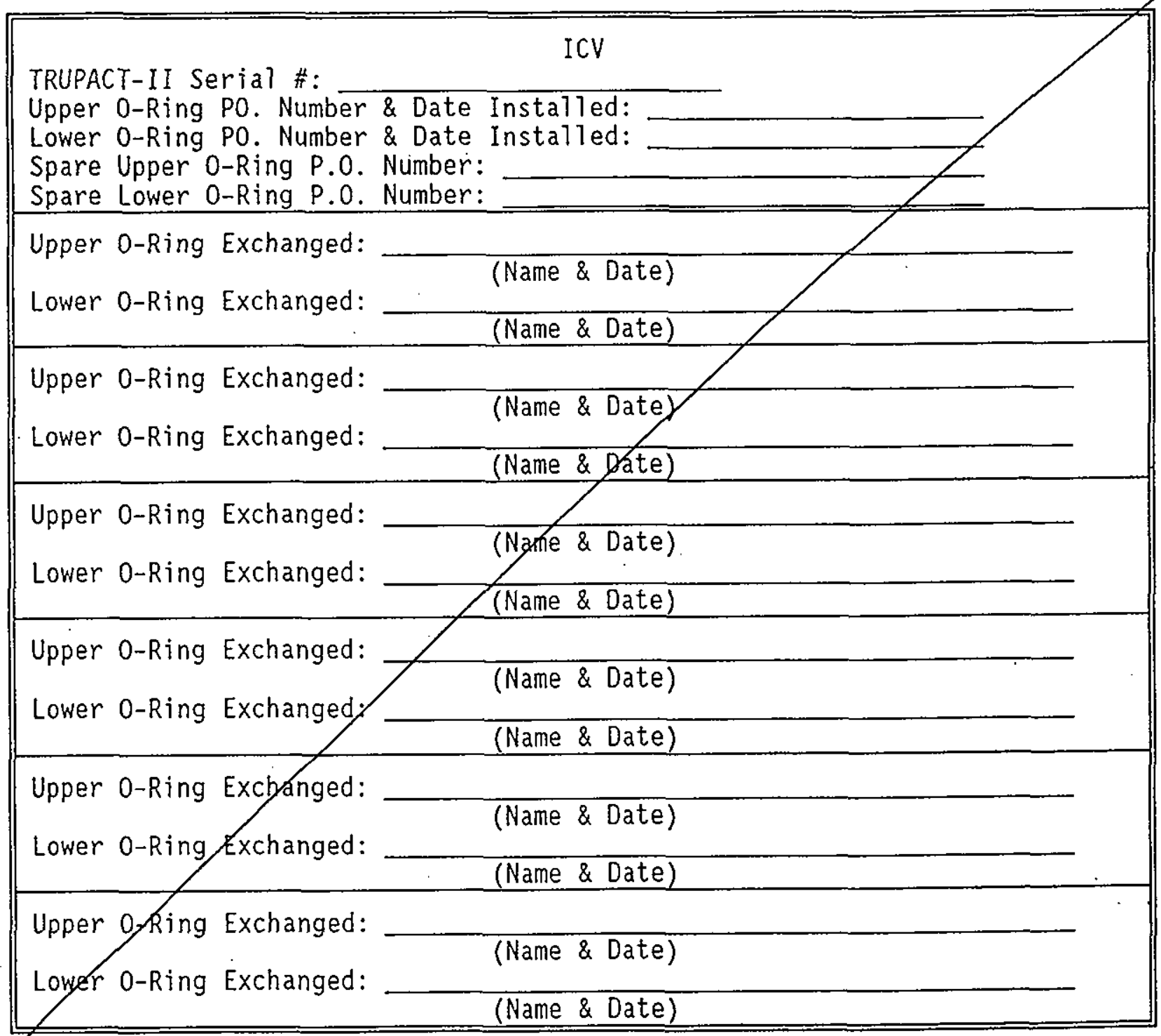




\section{RECEIVE AND LOAD TRUPACT-II CONTAINERS WRP1-OP-0521}

\section{ATTACHMENT 1 - TRUPACT-II Main 0-Ring Exchange Form Instructions - Either OCV or ICV Exchange Form}

Filling Out Upper Block

A new 0-Ring exchange form shall be started after annual maintenance has been performed. Any previous 0-Ring exchange forms shall be transmizted to the TRUPACT-II maintenance engineer for retention with the annual/maintenance records. For implementation on TRUPACT-IIs already in service, the exchange process will commence the next time main 0-Rings are replaced. In either case, both previously used sets of 0 -Rings (i.e., upper and lower installed \& spares) shall be replaced.

From the latest maintenance form, WP-1709, which replaced the main 0-Rings, record the "WIPP" Purchase Order number (P.0. \#) and the work instructions complete date on the appropriate lines.

From the 0-Ring protective package, for the spare set of 0 -Rings, record the "WIPP" Purchase Order number (P.O. \#) on the appropriate lines.

\section{Filling Out "Exchanged" Lines}

When a set of 0 -rings is exchanged h.e., the installed set is replaced with the spare set), record the date of/the exchange, and your name.

If an 0-Ring is replaced (i.e. a new 0-Ring is placed on the TRUPACT-II or in the spare 0-Ring bag), complete a maintenance record WP-1709 form. Process the maintenance record per DOE/WIPP 93-1001 and staple a copy of the WP-1700 form to the 0-Ring exchange form.

NOTE: If both the ICV and OCV have 0-Rings replaced at the same time, a copy of the maintenance record (WP-1709). should be attached to both $0-$ Ring exchange forms.

If all of the exchange lines are completed, staple another 0-Ring exchange form to the original and continue to record exchanges. The upper box on additional pagzs should be lined out.

If annual matintenance is being performed:

Reylace all of the main 0-Rings (i.e., installed and spared);

Initiate a new $0-$ Ring exchange form (i.e., complete data series in. upper box);

Attach the old exchange forms to the annual maintenance data package.

These forms may be reproduced locally as needed.

there are any questions concerning this process, please contact Clint

kelley at (505) 234-7498, or Tom Ward at (505) 234-7494. 


\section{WRP1-OP-0521}

ATTACHMENT 2 - TRUPACT-II LOADING DATA SHEET

\begin{tabular}{|c|c|c|}
\hline STEP NO. & DESCRIPTION & INITIALS \\
\hline & 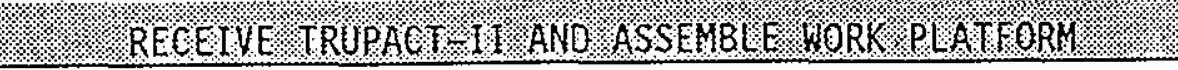 & \\
\hline 6.2 .1 & $\begin{array}{c}\text { Shipping Documents Reviewed and Complete } \\
\square \text { EMPTY. }\end{array}$ & \\
\hline $6.2 .1 . b$ & $\begin{array}{l}\text { O-Ring Pouches Included } \square \text { YES } \\
\text { Signature } \\
\text { Printed name }\end{array}$ & \\
\hline 6.2 .2 & $\begin{array}{l}\text { Radiation Survey Report Completed, per WRPI-OP-1225 } \\
\text { RSR Number } \\
\text { RCT's Signature } \\
\text { Printed name }\end{array}$ & \\
\hline 6.2 .3 & $\begin{array}{l}\text { TRUPACT-II Visthally Examined for Damage During Shipping } \\
\text { Signature } \\
\text { Printed name }\end{array}$ & \\
\hline & $\begin{array}{l}\text { Hoist \& Horizontal Platforms are FULLY RETRACTED } \\
\text { Signature } \\
\text { Printed name }\end{array}$ & \\
\hline $6.2 .7 . a$ & 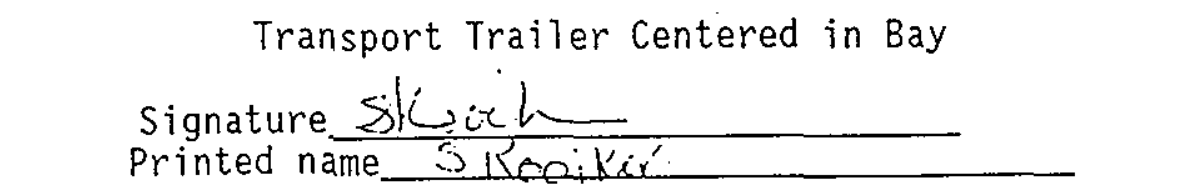 & \\
\hline $6.2 .7 . b$ & $\begin{array}{l}\text { Wheel Chocks Installed } \\
\text { Signature Skicil } \\
\text { Printed names Sooikic }\end{array}$ & \\
\hline $6.2 .7 . \mathrm{c}$ & $\begin{array}{l}\text { Trailer Stabilized } \\
\text { Signature Slicoll } \\
\text { Printed name S Sociker }\end{array}$ & \\
\hline $6.2 .7 . \mathrm{e}$ & Trailer Leveled & \\
\hline & $\begin{array}{l}\text { Signature } \frac{\text { Solieoll }}{\text { Srinted name Skoiker }} \\
\text { Pring }\end{array}$ & \\
\hline $6.2 .7 . f$ & $\begin{array}{l}\text { Trailer Stands Installed (Free Standing Trailers Only) } \\
\text { Signature NA Stil } \\
\text { Printed name__ }\end{array}$ & \\
\hline
\end{tabular}




\section{WRP1-OP-0521}

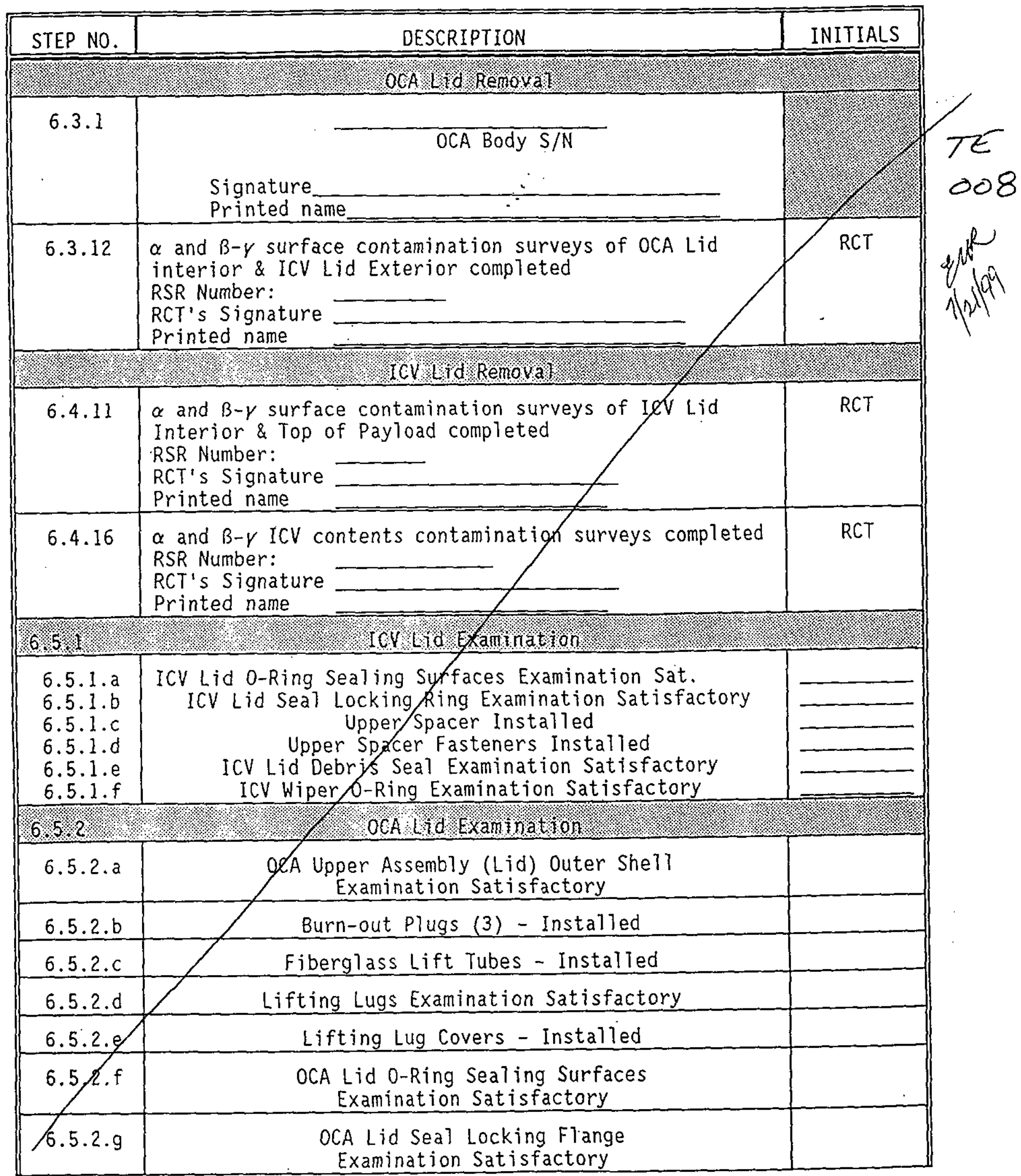




\section{WASTE RECEIVING AND PROCESSING (WRAP) FACILITY RECEIVE AND LOAD TRUPACT-II CONTAINERS WRP1-OP-0521}

\begin{tabular}{|c|c|c|}
\hline STEP NO. & DESCRIPTION & INITIALS \\
\hline $6.5 .2 . h$ & Z-Ring Screws - Present and Tight & \\
\hline $6.5 .2 . i$ & Guide Plates and Screws - Present and Tight & \\
\hline $6.5 .2 . j$ & Test Port Access Threads - Clean and Examine & \\
\hline 6.5 .3 .3 .8$. & 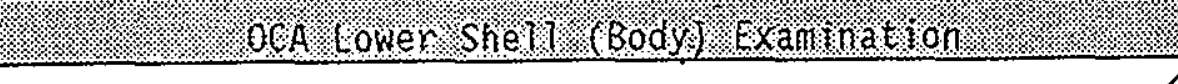 & \\
\hline $6.5 .3 . a$ & $\begin{array}{c}\text { OCA Lower Assembly Outer She } 11 \\
\text { Examination Satisfactory }\end{array}$ & \\
\hline $6.5 .3 . \mathrm{b}$ & Burn-out Plugs (6) - Installed & \\
\hline $6.5 .3 . c$ & Locking Ring Bolt Threaded Inserts (6) - Installed & \\
\hline $6.5 .3 . d$ & Ceramic Fiber Gasket - Installed & \\
\hline $6.5 .3 . \mathrm{e}$ & OCA Upper \& Lower Main 0-Ring Examination Satisfactory & \\
\hline $6.5 .3 . f$ & OCA Locking Ring Flange Examination Satisfactory & \\
\hline $6.5 .3 . \mathrm{g}$ & O-Ring Grooves - Clean and Undamaged & \\
\hline $6.5 .3 . \mathrm{h}$ & Vent-Port Threads - clezh and Undamaged & \\
\hline $6.5 .3 . i$ & Seal-Test Port Threads / Clean and Undamaged & \\
\hline 6.5 .4$. & (1.: & \\
\hline $\begin{array}{l}6 \cdot 5 \cdot 4 \cdot \mathrm{a} \\
6 \cdot 5 \cdot 4 \cdot \mathrm{b} \\
6 \cdot 5 \cdot 4 \cdot \mathrm{c} \\
6 \cdot 5 \cdot 4 \cdot \mathrm{d} \\
6 \cdot 5 \cdot 4 \cdot \mathrm{e} \\
6 \cdot 5 \cdot 4 \cdot \mathrm{f} \\
6 \cdot 5 \cdot 4 \cdot \mathrm{g} \\
6 \cdot 5 \cdot 4 \cdot \mathrm{h} \\
6 \cdot 5 \cdot 4 \cdot \mathrm{i} \\
6 \cdot 5 \cdot 4 \cdot \mathrm{j}\end{array}$ & 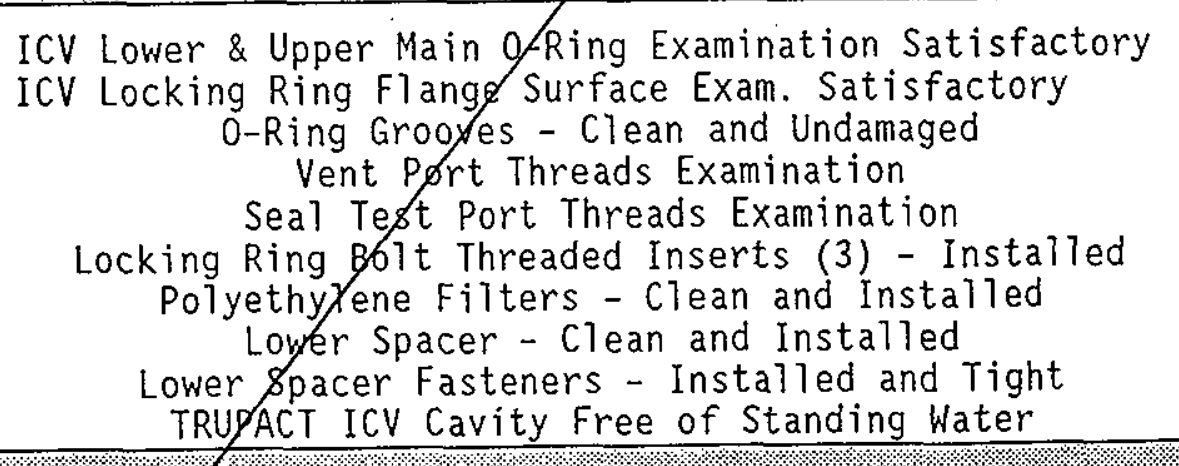 & \\
\hline 6.5 .5$. & ICV component Examinat lon & \\
\hline $\begin{array}{l}6 \cdot 5 \cdot 5 \cdot \mathrm{a} \\
6 \cdot 5 \cdot 5 \cdot \mathrm{b} \\
6 \cdot 5 \cdot 5 \cdot \mathrm{c} \\
6 \cdot 5 \cdot 5 \cdot \mathrm{d} \\
6 \cdot 5 \cdot 5 \cdot \mathrm{e} \\
6 \cdot 5 \cdot 5 \cdot \mathrm{f} \\
6 \cdot 5 \cdot 5 \cdot \mathrm{g} \\
6 \cdot 5 \cdot 5 \cdot \mathrm{h} \\
6 \cdot 5 \cdot 5 \cdot \mathrm{i} \\
6 \cdot 5 \cdot 5 \cdot \mathrm{j} \\
6 \cdot 5 \cdot 5 \cdot \mathrm{k} \\
6 \cdot 5 \cdot 5 \cdot 1\end{array}$ & $\begin{array}{l}\text { ICV Vont Port Cover and Gasket } \\
\text { ICV Yent Port Outer Plug } \\
\text { O-ying Intact and Clean } \\
\text { ILV Vent Port Inner Plug and 0-Ring } \\
\text { O-ring Intact and Clean } \\
\text { ICV Seal Test Port Plug and O-Ring } \\
\text { O-ring Intact and Clean } \\
\text { Locking Ring Bolts (3) } \\
\text { ICV Upper Main 0-ring } \\
\text { O-ring Clean and Installed } \\
\text { ICV Lower Main 0-ring } \\
\text { O-ring Clean and Installed }\end{array}$ & \\
\hline
\end{tabular}


WRP1-OP-0521

Rev/Change A-1

Printed: May 5, 1999

PAGE 39 of 43

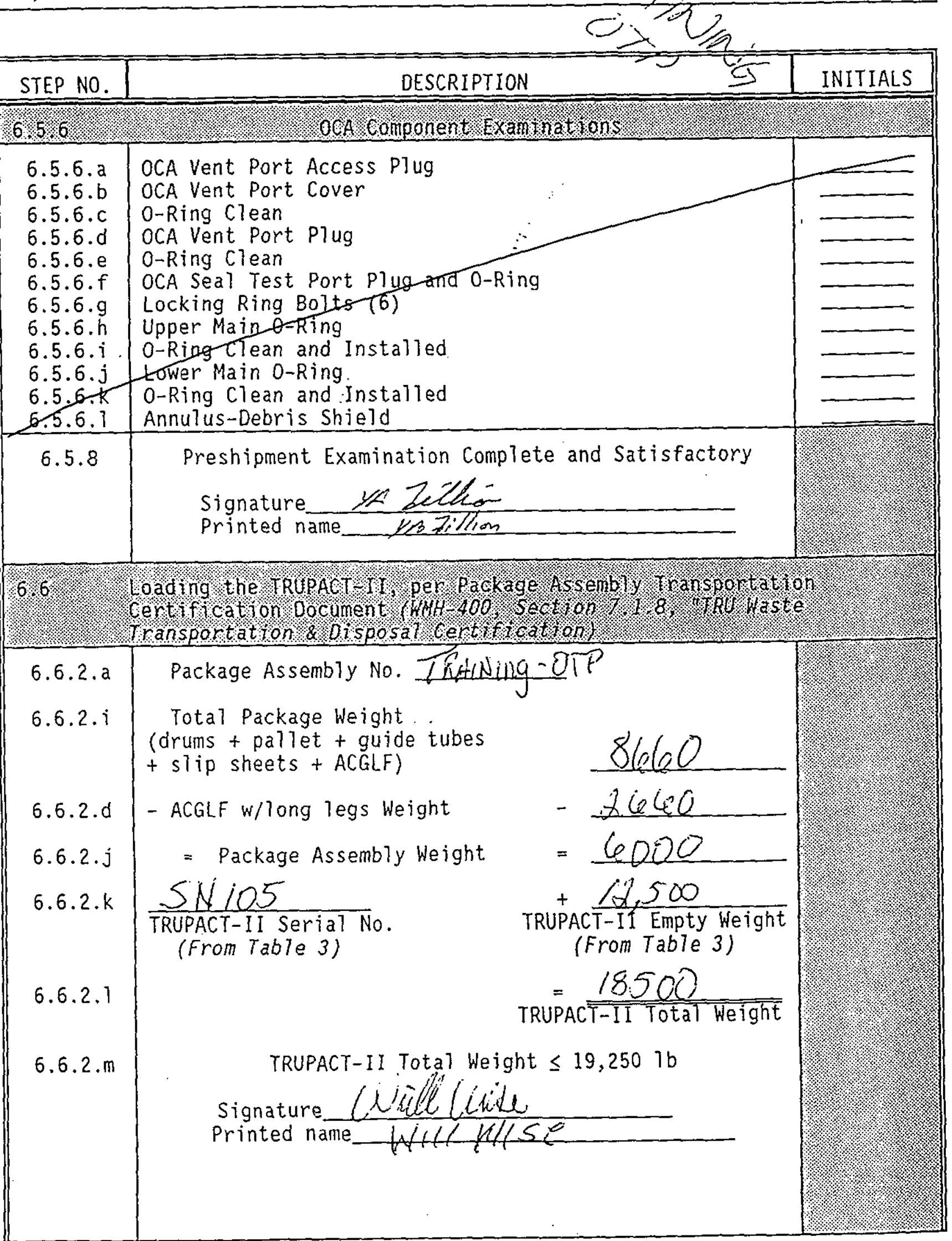




\section{WASTE RECEIVING AND PROCESSING (WRAP) FACILITY RECEIVE AND LOAD TRUPACT-\|I CONTAINERS WRP1-OP-0521}

\begin{tabular}{|c|c|c|}
\hline STEP NO. & DESCRIPTION & INITIALS \\
\hline 6.2 & 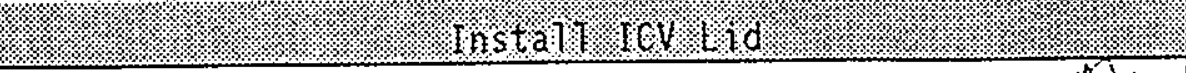 & \\
\hline 6.7 .2 & 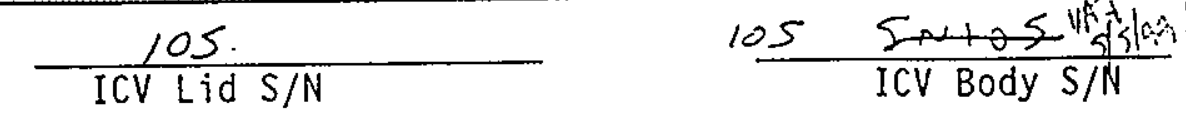 & \\
\hline & $\begin{array}{l}\text { Signature ys Zell } \\
\text { Printed name ye } 7 \text { ylion: }\end{array}$ & \\
\hline 6.7 .3 .1 & $\begin{array}{l}3 \text { ICV Lock Ring Bolts Torqued } 28-32 \mathrm{ft}-1 \mathrm{~b} \\
\text { Tool ID } \#: 465-88-010004 \text { J Cal. Due Date: } 2 / 22 / 00 \\
\text { QC's Signature } \\
\text { Printed name D.L.VANCE }\end{array}$ & $Y A]$ \\
\hline $6.7 .3 . n$ & 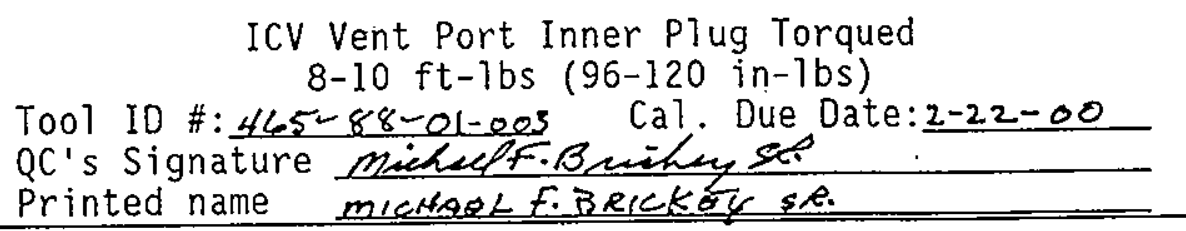 & $1 / 23$ \\
\hline $6.7 .3 . p$ & $\begin{array}{l}\text { ICV Assembly Verification Leak Test } \\
\text { Signature Glaine Vufkens } \\
\text { Printed name Blaike Hackins }\end{array}$ & \\
\hline 6.7 .3 .9 & 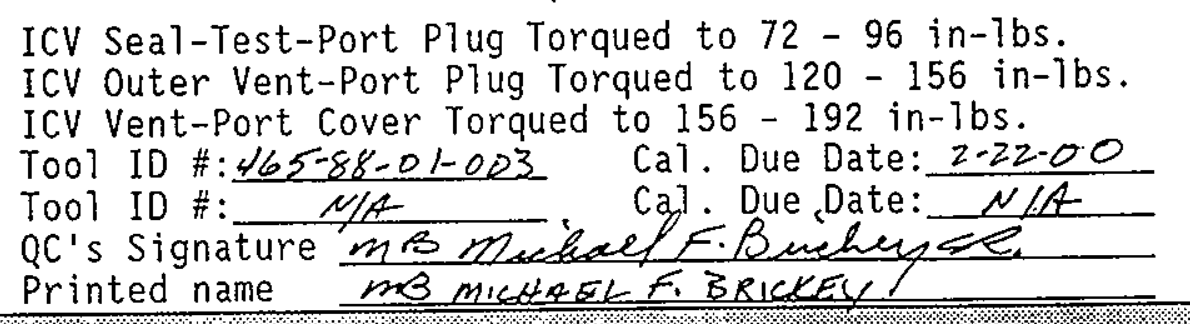 & $\frac{\frac{1 / 47}{1 / 47}}{\frac{1 / 47}{1 / 2}}$ \\
\hline 6.8 & (d. Installation & \\
\hline 6.8 .2 & 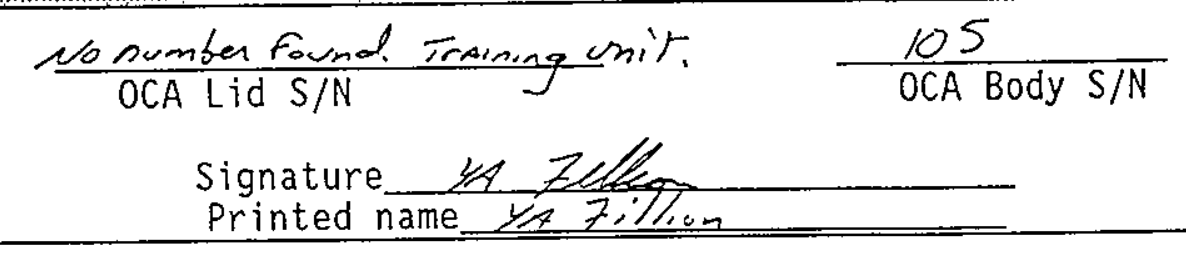 & \\
\hline $6.8 .3 . \mathrm{m}$ & 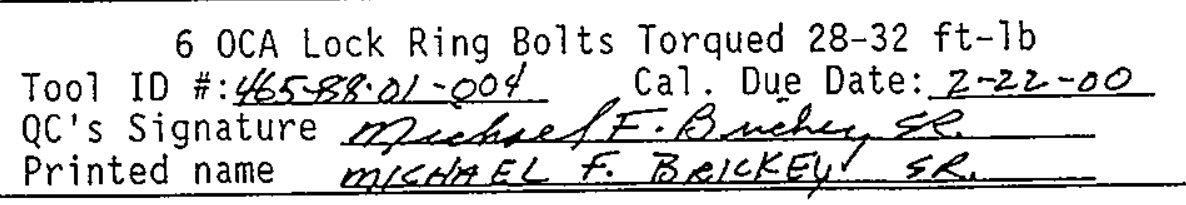 & $1 / 27$ \\
\hline 6.8 .3 .0 & 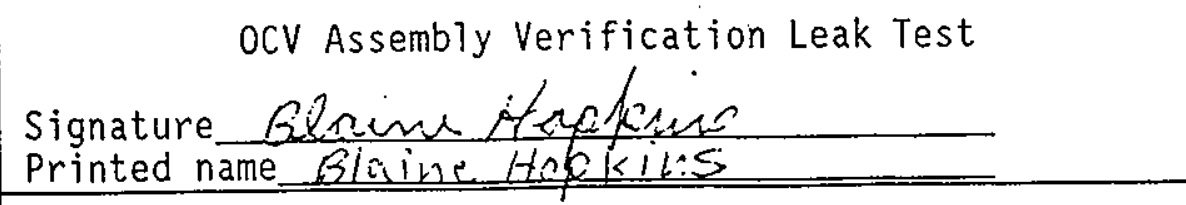 & \\
\hline 6.8 .3 & OCA Lid Lifting Pocket Covers Installed & $N_{1}$ \\
\hline
\end{tabular}




\section{WASTE RECEIVING AND PROCESSING (WRAP) FACILITY \\ RECEIVE AND LOAD TRUPACT-II CONTAINERS WRP1-OP-0521}

\begin{tabular}{|c|c|c|}
\hline STEP NO. & DESCRIPTION & INITIALS. \\
\hline 6.8 .3 .9 & 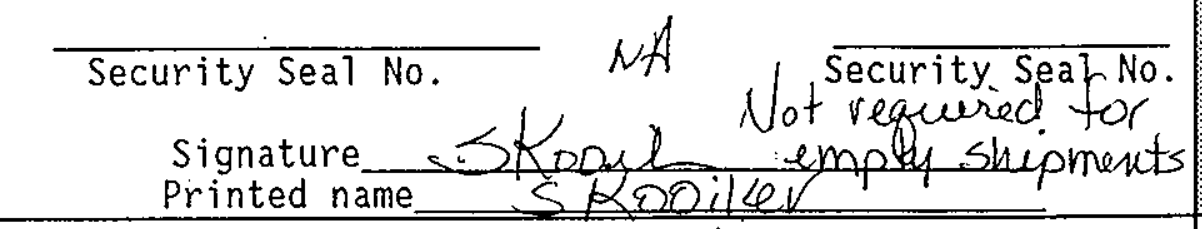 & \\
\hline $6.8 .3 \cdot r$ & 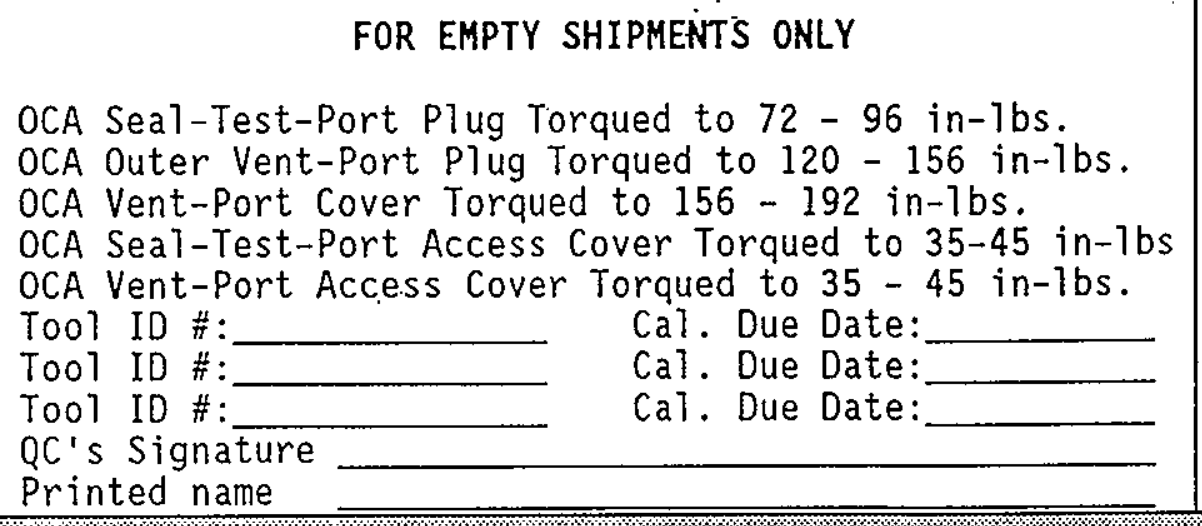 & \\
\hline 8 & 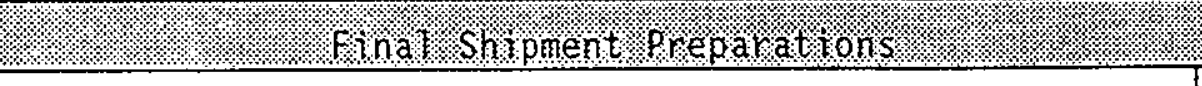 & \\
\hline 6.9 .1 & $\begin{array}{l}\text { Surface Contamination Survey Highest Results recorded } \\
\text { on RSR, per WRPI-OP-1225 RSR Number } \\
\text { RCT's Signature } \\
\text { Printed name }\end{array}$ & $\begin{array}{l}\text { RCT } \\
\text { Whit } \\
\text { suivirefte }\end{array}$ \\
\hline 6.9 .2 & $\begin{array}{l}\text { Direct Radiation Survey Results recorded on RSR, per } \\
\text { WRP1-OP-1225 } \\
\text { RCT'S Signature Number } \\
\text { Printed name }\end{array}$ & RCT \\
\hline 6.9 .3 & $\begin{array}{l}\text { TRUPACT Exterior (1 Meter) results recorded on RSR, per } \\
\text { WRP1-OP-1225 } \\
\text { RCT's Signature Number } \\
\text { Printed name }\end{array}$ & RCT \\
\hline 6.9 .11 & $\begin{array}{l}\text { Tie-Down Device Adjystment Nuts Properly Gapped } \\
\text { Signature i fids } \\
\text { Printed name }\end{array}$ & \\
\hline 6.9 .12 & $\begin{array}{l}\text { TRUPACT Package Marking and Labeling in Compliance } \\
\text { Signature SKoril } \\
\text { Printed names Sooiks' }\end{array}$ & \\
\hline $\begin{array}{l}6.9 .13 \\
6.9 .14\end{array}$ & $\begin{array}{l}\begin{array}{l}\text { O-Ring Pouches Included } \square \text { YES } \\
\text { Data Sheet Completed \& Submitted to No }\end{array} \\
\begin{array}{l}\text { NPO's signature } \\
\text { Printed name } \\
\text { Date }\end{array}\end{array}$ & \\
\hline
\end{tabular}


WASTE RECEIVING AND PROCESSING (WRAP) FACILITY

RECEIVE AND LOAD TRUPACT-II CONTAINERS WRP1-OP-0521

Rev/Change A-1

Printed: May 5, 1999

PAGE 42 of 43

\begin{tabular}{|c|c|c|c|}
\hline STEP NO. & & DESCRIPTION & INITIALS \\
\hline 6.9 .15 & $\begin{array}{l}\text { TCO Revie } \\
\text { TCO's Signature } \\
\text { Printed name } \\
\text { Date }\end{array}$ & 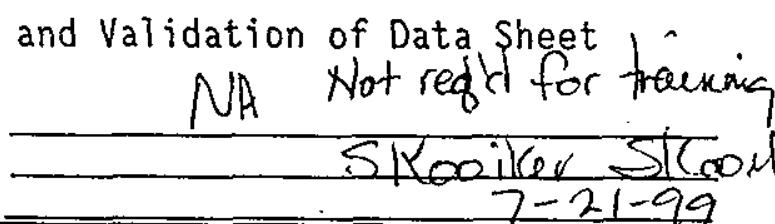 & \\
\hline
\end{tabular}
COMMENTS/OBSERVATIONS (indicate applicable Step No.):

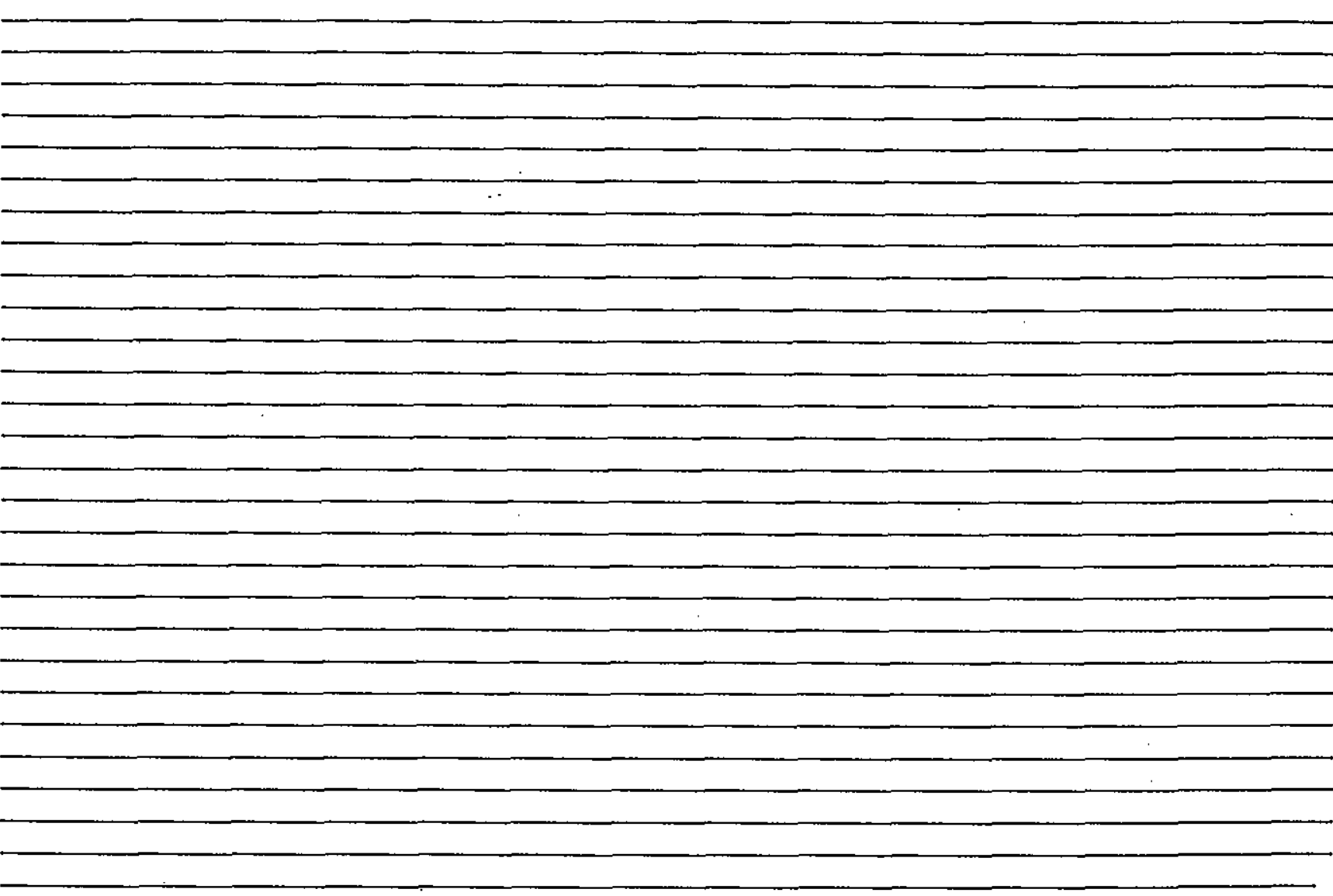



WRP1-OP-0521

\section{ATTACHMENT 3 - GLOSSARY}

(ACGLF) Adjustable Center-of-Gravity Lift Fixture

(ACES) Access Control Entry System

(DVS) Dock Vacuum System

(ICV) Inner Containment Vessel

(OCA) Outer Containment Assembly

(OMI) TRUPACT-II Operating and Maintenance Instructions

(PATCD) Package Assembly Transportation Certification Document

(RSR) Radiological Survey Report

(TCO) Transportation Certification Official

(TRUPACT-II) Transuranic Package Transporter-II

(VOC) Volatile Organic Compounds

(WIPP) Waste Isolation Pilot Plant 
TRUPACT-II PAYLOAD ASSEMBLY

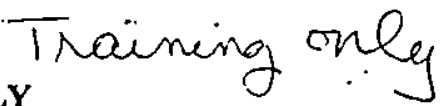

TRANSPORTATION CERTIFICATION DOCUMENT (PATCD), Page 1 of 2

\section{DENTIRTCATIONPARAMTIERS}

Shipment No.: Training

TRUPACT-II OCA Body/Lid Nos.:

$\mathrm{XXX}$

$\operatorname{IXXX}$

Payload Shipping Category: 3003400660 Category Decay Heat Limit (W): 0.0215 W/drum, 0.2898/TRUPACT-II
Type of Payload: $\square$ SWBs $\triangle D R U M S$
0 TDOP
$\square$ PIPE OVERPACKSDate ICV

Closed:

\section{PA 1. OAD GERTIMICATIONPARAMHTERS}

Bottom Assembly Weight plus RMS Error $(A+C)(\mathrm{lbs}):$ 2.981 Decay Heat plus Error (watts): 2.60E-2 W

Top Assembly Weight Plus RMS Error (B+D) (lbs): $2.80 i^{-}$

Total Weight plus RMS Error: 5,782

Fissile Mass (FGE) plus 2 X Error: $8.70 E+01$

TRUPACT-II Dose Rates (mRem/hr): Contact

(Q) 2 meters

in $\mathrm{Cab}$

Bottom Weight $\geq$ Top Weight

$\mathbb{R}$

Total Weight plus Error $\leq 7,265 \mathrm{lbs}, \&$

Decay Heat plus Error $\leq$ Category Limit $\mathbb{Z}$

Fissile Mass (Pu-239 FGE) plus 2 X Error $\leq 325$ grams $\notin$

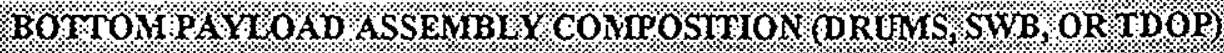

\begin{tabular}{|c|c|c|c|c|c|c|}
\hline $\begin{array}{c}\text { Container } \mathbb{L}^{b} \\
\text { Number }\end{array}$ & $\begin{array}{l}\text { Weight } \\
\text { (lb) }\end{array}$ & $\begin{array}{l}\text { Error } \\
\text { (lb) }\end{array}$ & $\begin{array}{l}\text { Decay Heat } \\
\text { (W) }\end{array}$ & $\begin{array}{l}\text { Error } \\
\text { (W) }\end{array}$ & $\begin{array}{l}\text { Fissile Mass } \\
\text { (FGE) }\end{array}$ & $\begin{array}{l}\text { Error } \\
\text { (FGE) }\end{array}$ \\
\hline 6 & 440 & 0.44 & $1.77 \mathrm{E}-03$ & $1.52 \mathrm{E}-03$ & $7.26 \mathrm{E}+00$ & $1.16 \mathrm{E}-01$ \\
\hline 11 & 440 & 0.44 & $1.67 \mathrm{E}-03$ & $1.43 \mathrm{E}-03$ & $6.85 E+00$ & $1.10 \mathrm{E}-01$ \\
\hline 1 & 420 & 0.42 & $1.90 \mathrm{E}-03$ & $1.63 \mathrm{E}-03$ & $7.79 E+00$ & $1.25 \mathrm{E}-01$ \\
\hline 3 & 420 & 0.42 & $1.65 \mathrm{E}-03$ & $1.42 \mathrm{E}-03$ & $6.77 \mathrm{E}+00$ & $1.09 \mathrm{E}-01$ \\
\hline 4 & 420 & 0.42 & $9.70 \mathrm{E}-04$ & 8.32E-04 & $3.98 \mathrm{E}+00$ & $6.38 \mathrm{E}-02$ \\
\hline 7 & 420 & 0.42 & $8.00 \mathrm{E}-04$ & $6.86 \mathrm{E}-04$ & $3.28 \mathrm{E}+00$ & $5.26 \mathrm{E}-02$ \\
\hline 8 & 420 & 0.42 & $2.00 \mathrm{E}-03$ & $1.72 E-03$ & $8.20 \mathrm{E}+00$ & $1.32 \mathrm{E}-01$ \\
\hline Subtotal (A) & 2980 & . & 0.0108 & & 44.12 & \\
\hline $\begin{array}{l}\text { Subtotal RMS } \\
\text { Error }^{\circ}(\mathrm{C})\end{array}$ & & $1.06 \mathrm{E}+00$ & & & & \\
\hline $\begin{array}{ll}\text { a } & \text { Total weigh } \\
\text { b } & \text { Use Top Pa } \\
\text { c } & \text { Error }=\mathrm{Roc}\end{array}$ & npo & $\begin{array}{l}\text { led by w } \\
\text { e to com } \\
\text { uare roo }\end{array}$ & $\begin{array}{l}\text { entire pay } \\
\text { cording of } \\
\text { sum of the }\end{array}$ & embly. & ). & \\
\hline
\end{tabular}




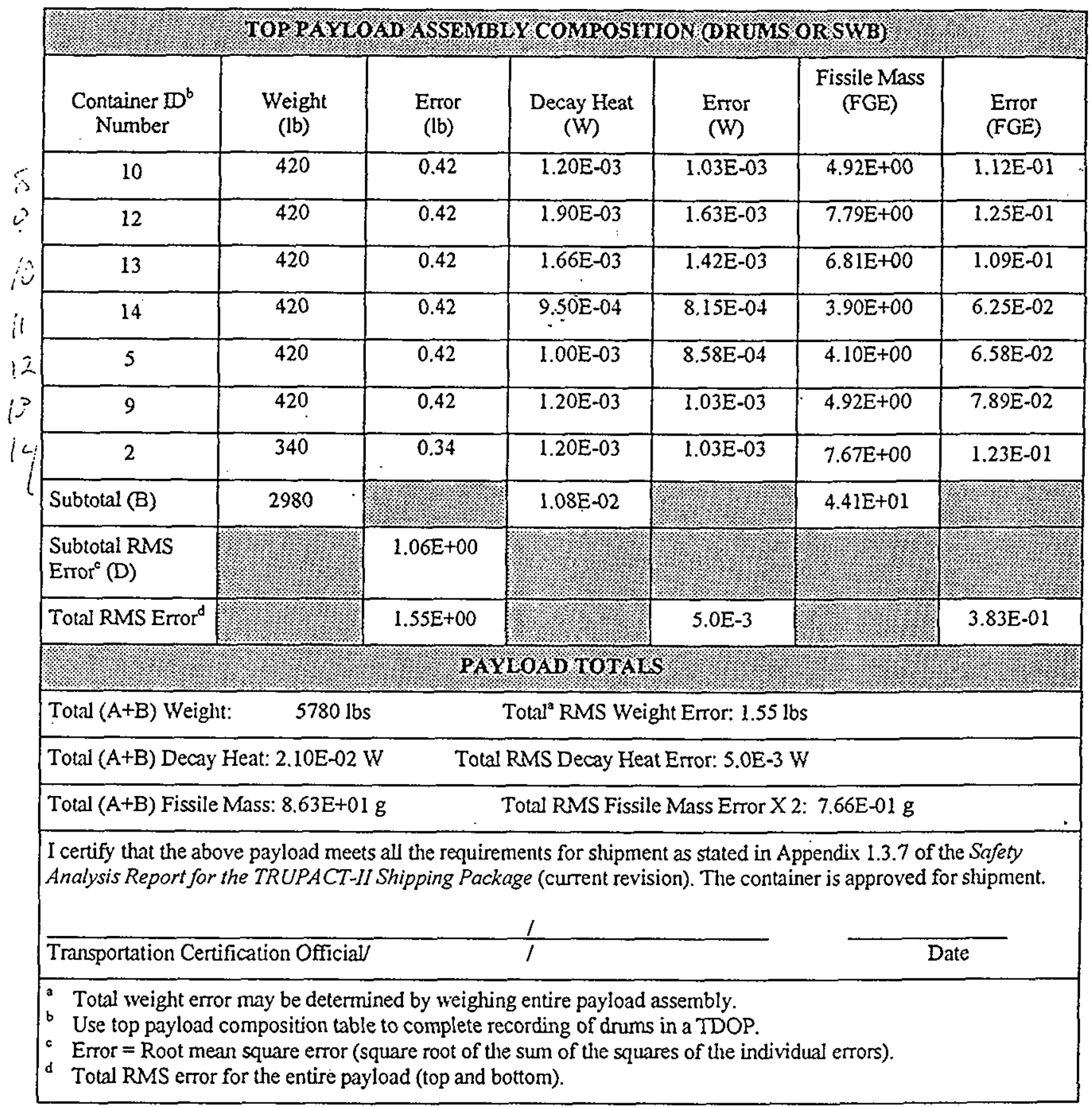


nponent Number

Component Name PM/S Title

$R-05-103$

CRANE

J-CR-05-103 CRANE
Procedure Number PM/S Num Type Loop/Seq SC Admin Group Last Done Next Due. RB Freq Res Est Hrs

$\mathrm{PM} / \mathrm{S}$ Authority

\section{WRP-PMI -0508 W1-003835}

MONTHLY BRIOGE CRANE INSP. ANDERSON,SP

WRP-PMI-0509 W1-00557 5

ANNUAL BRIDGE CRANE INSP

GRAF.BJ

$04 / 28 / 99 \quad 05 / 22 / 99$

25

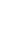

9

232

=a) Number of Records Reported: 2

$\begin{array}{cccccc}07 / 30 / 98 & 06 / 25 / 99 & 1 & 330 & 04 A & 4 \\ & & 10 & 22 & \therefore & 4 \\ & & & & 35 & 4 \\ & & & & 23 & 1\end{array}$


HELIUM LEAK TEST OF THE TRUPACT-II SHIPPING CONTAINER

\section{WRP1-OP-0524}

\section{TORQUE DATA SHEET}

\begin{tabular}{|c|c|c|}
\hline STEP No. & DESCRIPTION & $\begin{array}{l}\text { INITIALS } \\
\text { and } \\
\text { DATE }\end{array}$ \\
\hline 6.3 .1 & $\begin{array}{l}\text { ICV bolts torqued to } 2832 \mathrm{ft}-1 \mathrm{bs} \\
\text { Torque Wrench Id. } 465-88-0 /-004 \text { Cal. Due Date } 2 \cdot 22.00 \text {, }\end{array}$ & $\begin{array}{l}143 \\
5-6-99\end{array}$ \\
\hline 6.3 .13 & $\begin{array}{l}\text { ICV vent-port-plug torqued to } 120-156 \text { in-lbs } \\
\text { Torque Wrench Id. } 465-88-0)-003 \mathrm{CaT} \text {. Due Date } 2-22-00\end{array}$ & $\begin{array}{l}\ln 3 \\
5-6-49\end{array}$ \\
\hline 6.3 .15 & $\begin{array}{l}\text { ICV seal-test-port-plug torqued to } 72-96 \text { in-lbs } \\
\text { Torque Wrench Id. } 465-88-01-003 \mathrm{Ca} \text {. Due Date } 2-z z-00\end{array}$ & $\begin{array}{c}\sin \beta \\
5-6-49\end{array}$ \\
\hline 6.3 .20 & $\begin{array}{l}\text { ICV vent-port cover bolts torqued to } 156-192 \text { in-ibs } \\
\text { Torque Wrench Id. } 465-88-01-003 \text { Cal. Due Date } 2-2 z-00\end{array}$ & $5-6-49$ \\
\hline 6.7 .1 & $\begin{array}{l}\text { OCA Lid Bolts torqued to } 28-32 \text { ft-lbs } \\
\text { Torque Wrench Id. } 465-88-01-004 \text { Cal. Due Date } 2-22-00\end{array}$ & $5-6-49$ \\
\hline 6.7 .12 & $\begin{array}{l}\text { OCV vent-port plug torqued to } 120-156 \text { in-lbs } \\
\text { Torque Wrench Id. } \$ 65-88-01-003 \text { Cal. Due Date } 2-22-00\end{array}$ & $\begin{array}{l}\text { us } \\
5 \cdot 6 \cdot 99\end{array}$ \\
\hline 6.7 .14 & $\begin{array}{l}\text { OCV seal-test-port-plug torqued to } 72-96 \text { in-1bs } \\
\text { Torque Wrench Id. } 465-88-01-003 \mathrm{Cal} \text {. Due Date } 2-22-00\end{array}$ & $\begin{array}{r}\ln 9 \\
5-6-99\end{array}$ \\
\hline 6.7 .19 & $\begin{array}{l}\text { 0CV vent-port cover bolts torqued to } 156-192 \text { in-1bs } \\
\text { Torque Wrench Id. } 165-88-01-003 \text { Cal. Due Date } 2-22-00\end{array}$ & $\begin{array}{c}\text { WB } \\
5-6-99\end{array}$ \\
\hline 6.7 .20 & $\begin{array}{l}\text { OCV seal-test-port access plug torqued to } 35-45 \mathrm{ft}-1 \mathrm{bs} \\
\text { Torque Wrench Id. } 465-88.01-004 \mathrm{Ca} \text {. Due Date } z-22-00\end{array}$ & $\begin{array}{r}143 \\
5-6-99\end{array}$ \\
\hline 6.7 .21 & $\begin{array}{l}\text { OCV vent-port access plug torqued to } 35-45 \mathrm{ft}-1 \mathrm{bs} \\
\text { Torque Wrench Id. } 465-88-01-004 \mathrm{Ca} \text {. Due Date } 2-22-00\end{array}$ & $5-6-99$ \\
\hline
\end{tabular}

Facility

wRAP

ICV Lid S/M training cash $5 / N / 05$

ocV Lid $S / N$ training cash $5 / N / 0 S$ 


\section{LEAK TEST DATA SHEET}

Facility WRfe Date 4-6.99 Procedure No. Wefi-of-sisy Rev A-0

ICV Lid S/N $-10=$

ICV Body $S / N 105$

Temperature $20^{\circ} \mathrm{E}$ ident. Iay lor

Calibrated Helium Standard

Std. No. $584-40-03-013$

Std. Leak $3 \times 10^{-8}$ atm-cc/sec

Calib. Exp. $\frac{8-31-99}{}$

MSLD

Manufacturer $\frac{\text { LL } 100 \text { Plus }}{S}$

Ident. No. USE 486is

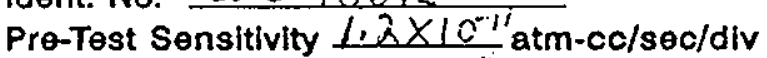

Post-Test Sensitivity $1 . \hat{2} \times 10^{-11} \mathrm{~atm}-\mathrm{cc} / \mathrm{sec} / \mathrm{div}$

Helium Backfill

Gage $534-31-0 ; \% 002$ Range 0-50 ESIf.

Callb. Exp. i0-i6-99

Atm. Pressure i4.3 f'sf

Evac. Pressure . . P PIA

He Backfill Pres. 19.3 fSIf

ICV Main Seal

Measured Leak Rate $8,6 \div 1,10$

Backgnd (subtract) $9 \times 10^{-7}$

Actual ICV Main Seal

Leak Rate Llo DeT RT Trublu Lrixk atm-cc/sec

ICV Outer Vent-Port-Plug Seal

Measured Leak Rate $3 \times 10^{-9}$

Backgnd (subtract) $2 \times 10^{-9}$

Actual ICV Outer Vent-Port-Plug

Leak Rate $6 \times 10^{-10}$ atm-cc/sec

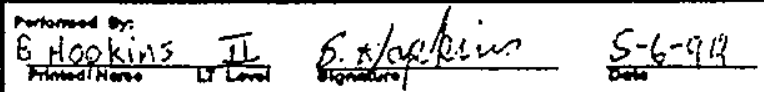

nomed or

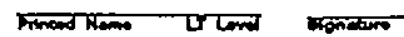

OCA Lid S/N

OCA Body S/N 105

Temperature 72 ident. Trylor

Calibrated Helium Standard

Std. No.

QJ Same as ICV

Std. Leak atm-cc/sec

Calib. Exp.

MSLD XSame as ICV

Manufacturer $\frac{U}{4} \quad 100.0125$

Ident. No. wie 4.3615

Pre-Test Sensltivity $\frac{1.3 \times 10^{-11}}{\text { atm-cc/sec/div }}$

Post-Test Sensitivity $1.3 \times 10^{-11}$ atm-cc/sec/div

Helium Backfill \Same as ICV

Gage Rango

Calib. Exp.

Atm. Pressure 14,3 FSIf

Evac. Pressure , 5 FSI.G

He Backill Pres. 14,3 PS If

\section{OCV Main Seal}

Measured Leak Rate $2.2 \times 10^{-9}$

Backgnd (subtract) $\frac{9.2 \times 10^{-9}}{9}$

Actual OCV Main Seal

Leak Rate No DeTostatole Leakatm-cc/sec

OCV Outer Vent-Port-PJug Seal Measured Leak Rate $2.2 \times 10^{-1}$

Backgnd (subtract) $4.4 \times 10^{-1}$

Actual OCV Outer Vent-Port-Plug

Leak Rate $1.4 \times 10^{-7}$ atm-cc/sec

moromes or

6.Hzkin; I Bthenens 5-6.99

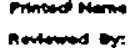

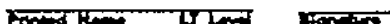




$$
\text { WRP1-OP-0524 }
$$

\section{ICV Main O-ring Seal Leak Test}

ICV

Seal-Test-Port
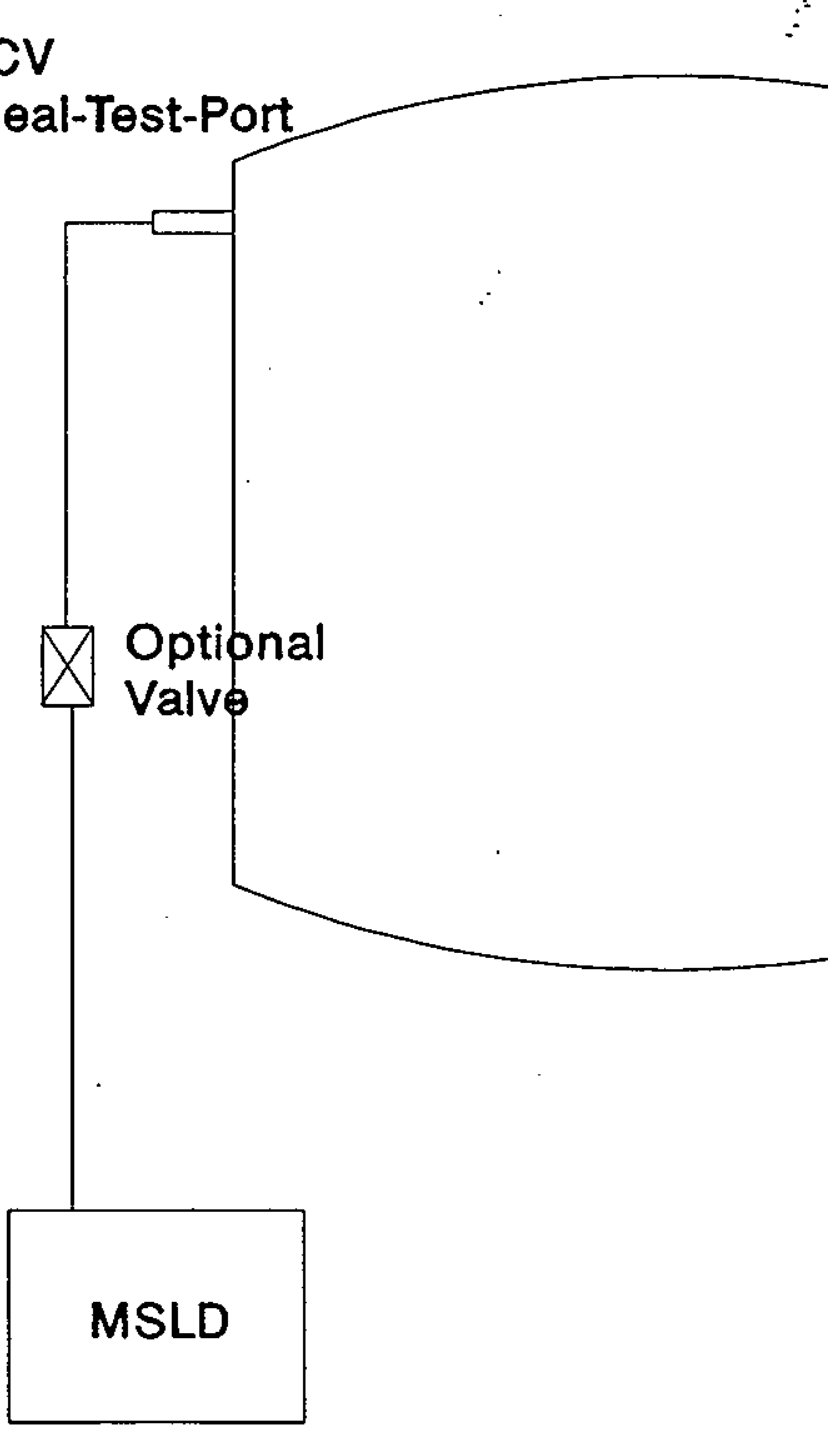
HELIUM LEAK TEST OF THE TRUPACT-II SHIPPING CONTAINER

\section{WRP1-OP-0524}

FIGURE 2. ICV Vent-Port Seal Leak Test

\section{ICV Vent-Port Seal Leak Test}

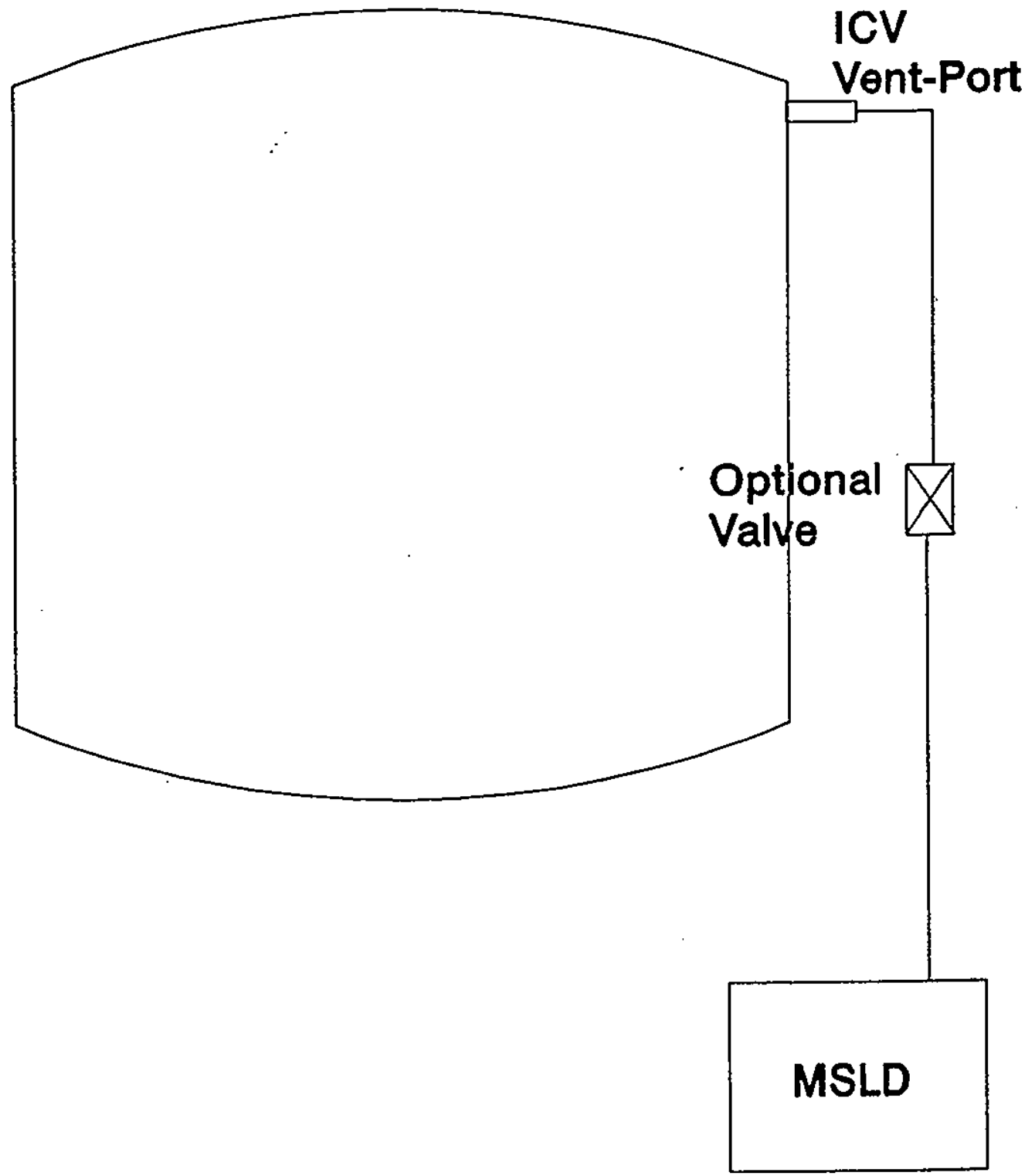




\section{OCV Main O-ring Seal Leak Test}

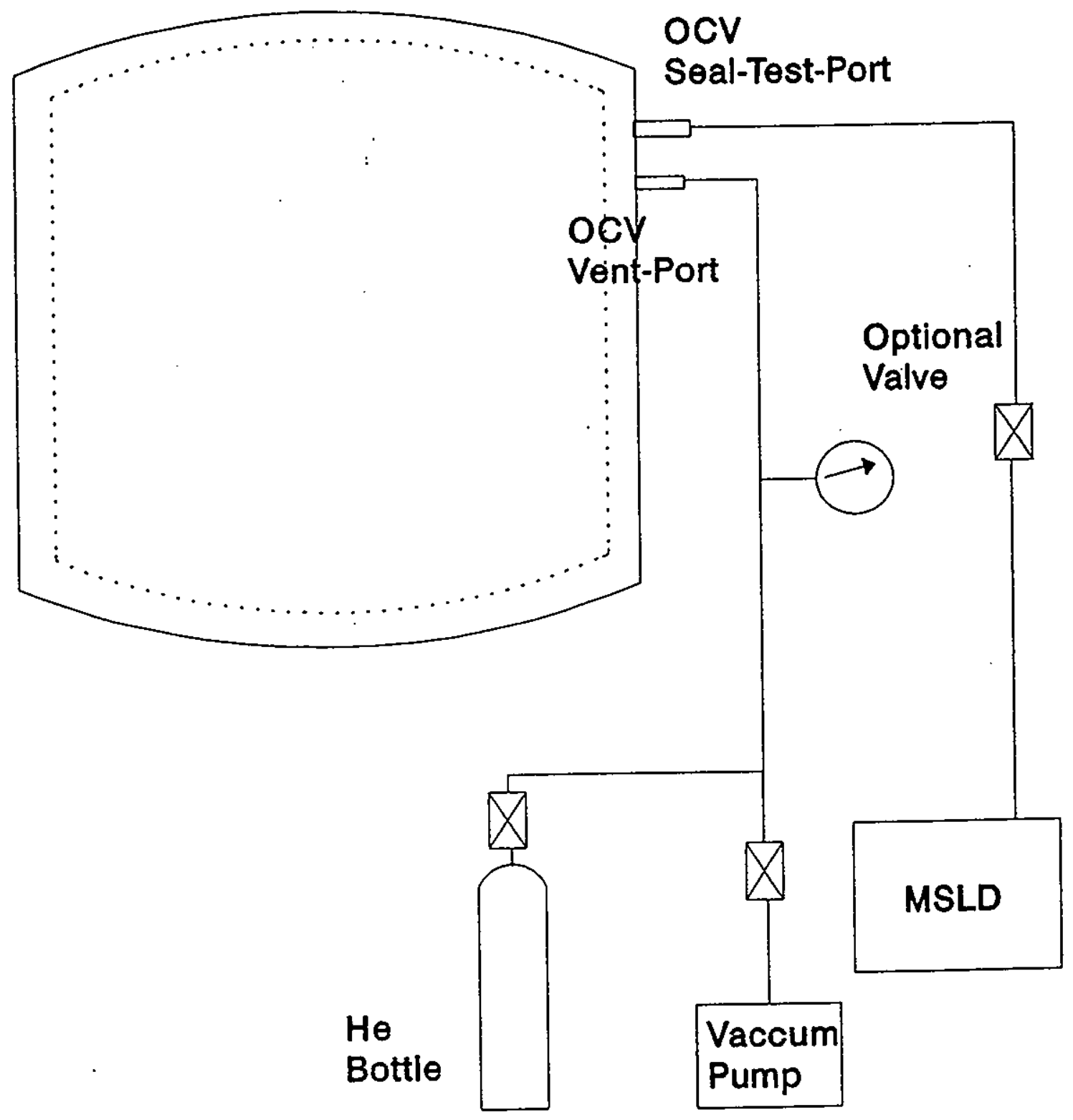



WRP1-OP-0524

\section{OCV Vent-Port Seal Leak Test}

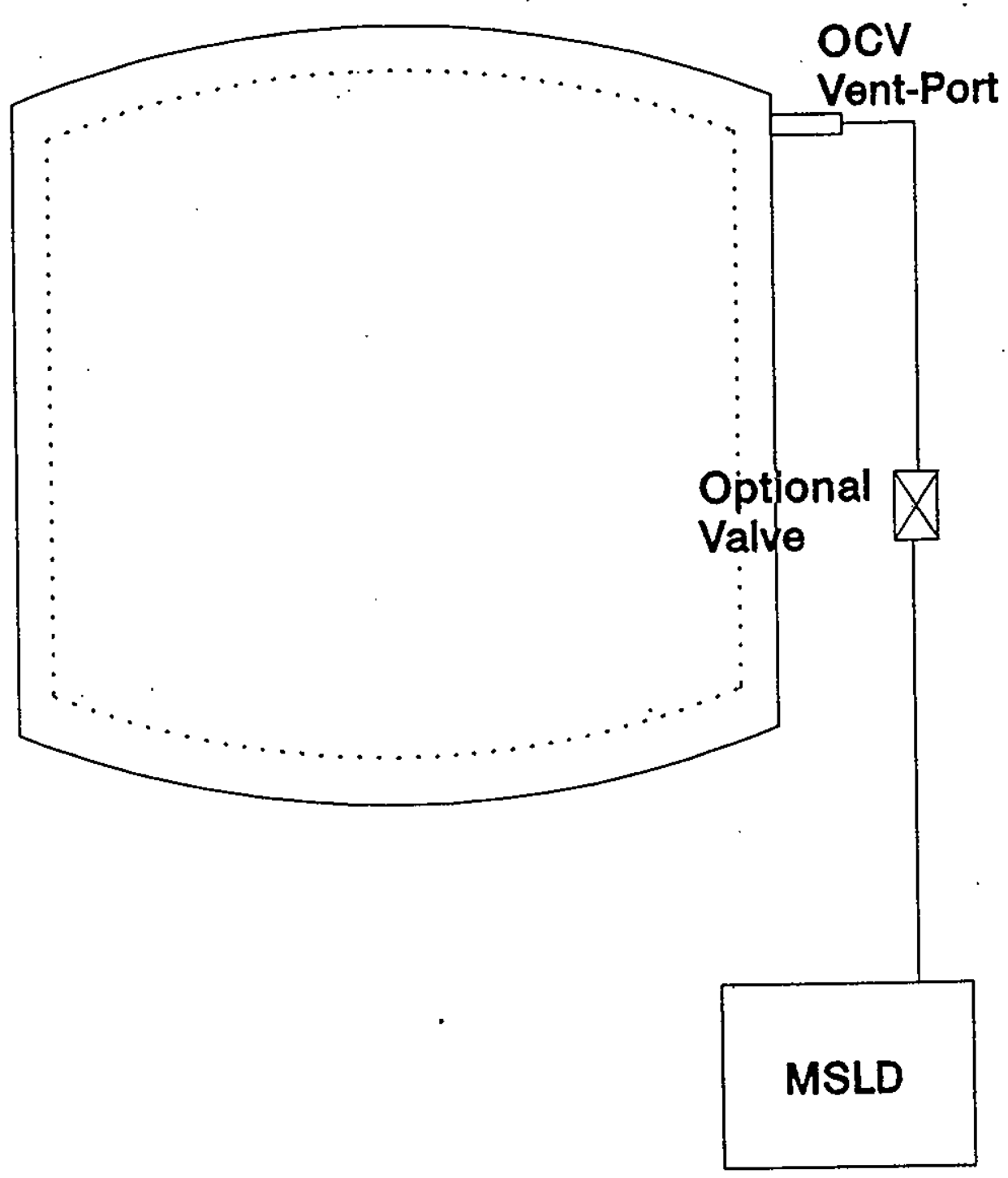




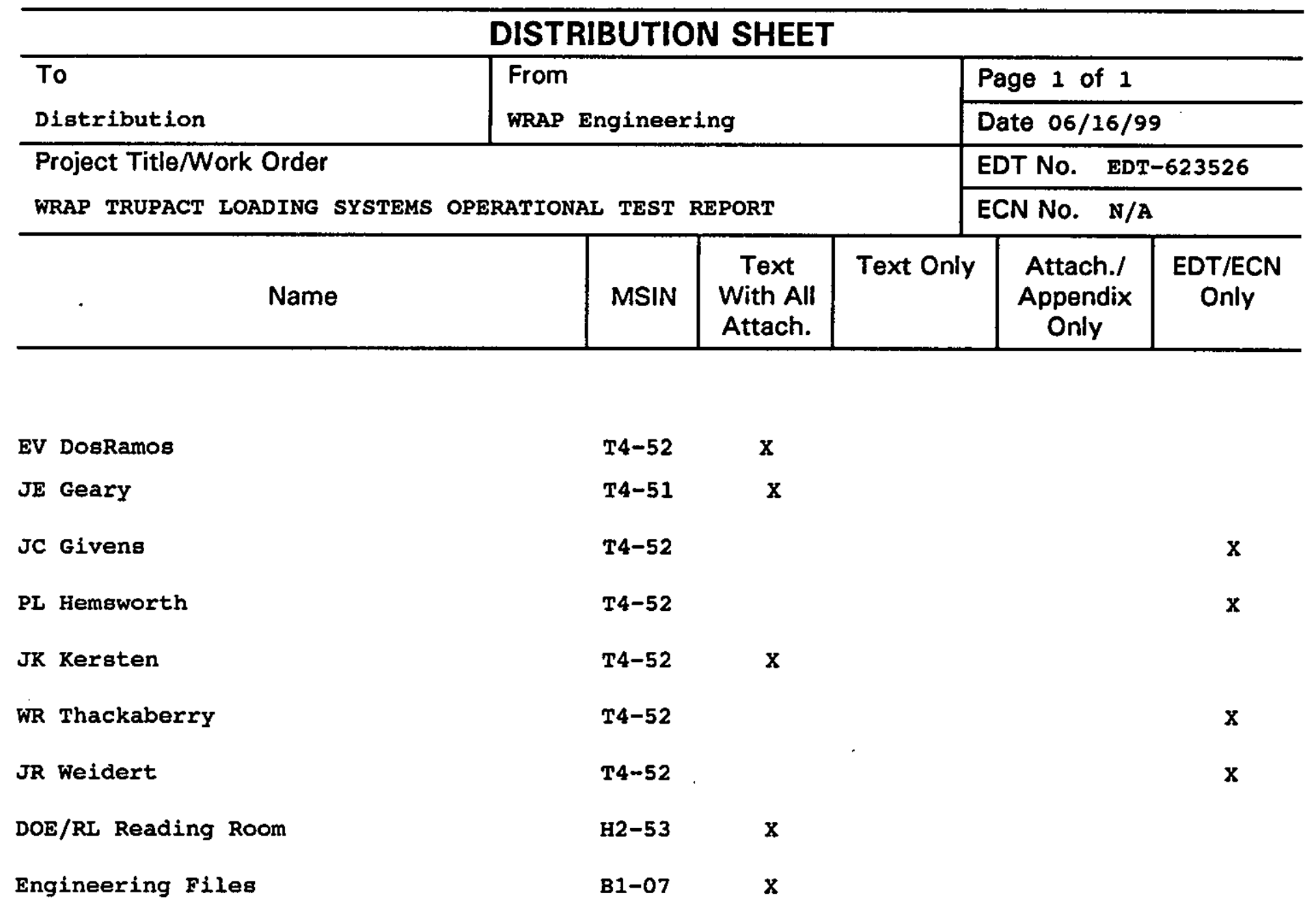

